NOAA Technical Report NMFS CIRC-394

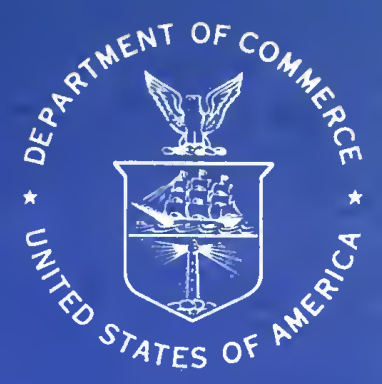

\title{
Marine Flora and Fauna of the Northeastern United States. Tardigrada
}

LELAND W. POLLOCK 


\section{NOAA TECHNICAL REPORTS}

\section{National Marine Fisheries Service, Circulars}

The major responsibilities of the National Marine Fisheries Service (NMFS) are to monitor and assess the abundance and geographic distribution of fishery resources, to understand and predict fluctuations in the quantity and distribution of these resources, and to establish levels for optimum use of the resources. IMFS is also charged with the development and implementation of policies for managing national fishing grounds, development and enforcement of domestic fisheries regulations, surveillance of foreign fishing off United States coastal waters, and the development and enforcement of international fishery agreements and policies. NIFS also assists the fishing industry through marketing service and economic analysis programs, and mortgage insurance and vessel construction subsidies. It collects, analyzes, and publishes statistics on various phases of the industry.

The NOAA Technical Report NMFSCIRC series continues a series that has been in existence since 1941. The Circulars are technical publications of general interest intended to aid conservation and management. Publications that review in considerable detail and at a high technical level certain broad areas of research appear in this series. Technical papers originating in economics studies and from management investigations appear in the Circular series.

NOA.A Technical Reports NMFS CIRC are available free in limited numbers to governmental agencies, both Federal and State. They are also available in exchange for other scientific and technical publications in the marine sciences. Individual copies may be obtained lunless otherwise noted) from D83. Technical Information Division. Environmental Science Information Center, NOAA, Washington, D.C. 20235. Recent Circulars are:

315. Synopsis of biological data on the chum salmon, Oncorhynchus keta (Walbaum) 1792. By Richard G. Bakkala. March 1970, iii + 89 p., 15 figs., 51 tables.

319. Bureau of Commercial Fisheries Great Lakes Fishery Laboratory, Ann Arbor, Michigan. By Bureau of Commercial Fisheries. March 1970, 8 p., 7 figs.

330. EASTROPAC Atlas: Vols. 1-7. Catalog No. I 49.4:330/(vol.) 11 vols Available from the Superintendent of Documents, U.S. Government Printing Office, Washington, D.C. 20402.

331. Guidelines for the processing of hot.smoked chub. By H. L. Seagran, J. T. Graikoski, and J. A. Emerson. January 1970, iv +23 p., 8 figs., 2 tables.

332. Pacific hake. (12 articles by 20 authors.) March 1970, iü +152 p., 72 figs., 47 tables.

333. Recommended practices for vessel sanitation and fish handling. By Edgar W. Bowman and Alfred Larsen. March 1970, iv +27 p., 6 figs.

335. Progress report of the Bureau of Commercial Fisheries Center for Estuarine and Menhaden Research, Pesticide Field Station, Gulf Breeze, Fla., fiscal year 1969. By the Laboratory staff. August 1970, iii +33 p., 29 figs., 12 tables.

336. The northern fur seal. By Ralph C. Baker, Ford Wilke, and C. Howard Baltzo. April 1970 , iij +19 p., 13 figs.

337. Program of Division of Economic Research, Bureau of Commercial Fisheries, fiscal year 1969. By Division of Economic Research, April 1970, uii +29 p., 12 figs., 7 tables.

338. Bureau of Commercial Fisheries Biological Laboratory, Auke Bay Alaska. By Bureau of Commercial Fisheries, June 1970, 8 p., 6 figs.

339. Salmon research at Ice Harbor Dam. By Wesley J. Ebel. April 1970, 6 p.. 4 figs.

340. Bureau of Commercial Fisheries Technological Laboratory, Gloucester, Massachusetts. By Bureau of Commercial Fisheries. June 1970, 8 p., 8 figs.

341. Report of the Bureau of Commercial Fisheries Biological Laboratory, Beaufort. N.C.. for the fiscal year ending June 30, 1968. By the Laboratory staff. August 1970 , iii +24 p., 11 figs., 16 tables.

342. Report of the Bureau of Commercial Fisheries Biological Laboratory St. Petersburg Beach, Florida, fiscal year 1969. By the Laboratory staff August 1970, iii +22 p., 20 figs., 8 tables.

313. Report of the Bureau of Commercial Fisheries Biological Laboratory, Galveston. Texas, fiscal year 1969. By the Laboratory staff. August 1970, ii Galveston, Texas, fiscal year
+39 p.. 28 figs., 9 tables.

344. Bureau of Commercial Fisheries Tropical Atlantic Biological Laboratory progress in research 1965-69, Miami, Florida. By Ann Weeks. October 1970, iv +65 p., 53 figs.,

346. Sportsman's guide to handling, smoking, and preserving Great Lakes coho salmon. By Shearon Dudley, J. T. Graikoski, H. L. Seagran, and Paul M. Earl. September 1970 , iii +28 p., 15 figs.

347. Synopsis of biological data on Pacific ocean perch, Sebastodes alutus By Richard L. Major and Herbert H. Shippen. December 1970, iii +38 p., 31 figs.. 11 tables.
349. Use of abstracts and summaries as communication devices in technical articles. By F. Bruce Sanford. February 1971, iii +11 p., 1 fig.

350. Research in fiscal year 1969 at the Bureau of Commercial Fisheries Biological Laboratory, Beaufort, N.C. By the Laboratory staff. November 1970, ii +49 p., 21 figs., 17 tables.

351. Bureau of Commercial Fisheries Exploratory Fishing and Gear Research Base, Pascagoula, Mississippi, July 1, 1967 to June 30. 1969. By Harvey R. Bullis, Jr. and John R. Thompson. November 1970, iv +29 p.. 29 figs., table.

352. Upstream passage of anadromous fish through navigation locks and use of the stream for spawning and nursery habitat, Cape Fear River, N.C., 1962-66. By Paul R. Nichols and Darrell E. Louder. October 1970, iv $+12 \mathrm{p}$. 9 figs., 4 tables.

356. Floating laboratory for study of aquatic organisms and their environ ment. By George R. Snyder. Theodore H. Blahm, and Robert J. McConnell. May 1971, iii +16 p., 11 figs.,

361. Regional and other related aspects of shellfish consumption - some preliminary findings from the 1969 Consumer Panel Survey. By Morton M. Miller and Darrel A. Nash. June 1971, iv +18 p., 19 figs., 3 tables, 10 apps.

362. Research vessels of the National Marine Fisheries Service. By Robert $\mathrm{S}$ Wolf. August 1971, uii +46 p., 25 figs., 3 tables. For sale by the Superintendent of Documents, U.S. Government Printing Office, Washington, D.C. 20402 .

364. History and development of surf clam harvesting gear. By Phillip S. Parker. October 1971, iv +15 p. 16 figs. For sale by the Superintendent of Documents, U.S. Government Printing Office, Washington, D.C. 20402.

365. Processing EASTROPAC STD data and the construction of vertical temperature and salinity sections by computer. By Forrest $R$. Miller and
Kenneth A. Bliss. February 1972 , iv +17 p., 8 figs., 3 appendix figs. For sale by the Superintendent of Documents, U.S. Government Printing Office Washington, D.C. 20402

366. Key to field identification of andromous juvenile salmonids in the Pacific Northwest. By Robert J. McConnell and George R. Snyder. January 1972, +6 p., 4 figs. For sale by the Superintendent of Documents, U.S Government Printing Office, Washington, D.C. 20402.

367. Engineering economic model for fish protein concentration processes. By K. K. Almenas, L. C. Durilla, R. C. Ernst, J. W. Gentry, M. B. Hale, and J. M. Marchello. October 1972, iii +175 p., 6 figs., 6 tables. For sale by the Superintendent of Documents, U.S. Government Printing Office, Washington D.C. 20402 . 368. Cooperative Gulf of Mexico estuarine inventory and study, Florida: Phase I, area description. By J. Kneeland McNulty. William N. Lindall, Jr.,
and James E. Sykes. November 1972 , vii +126 p., 46 figs., 62 tables. For sale by the Superintendent of Documents, U.S. Government Printing Office Washington, D.C. 20402

369. Field guide to the anglefishes (Pomacanthidae) in the western Atlantic By Henry A. Feddern. November 1972, iü +10 p., 17 figs., For sale by the Superintendent of Documents, U.S. Government Printing Office, Washington 
NOAA Technical Report NMFS CIRC-394

\title{
Marine Flora and Fauna of the Northeastern United States. Tardigrada
}

\author{
LELAND W. POLLOCK
}

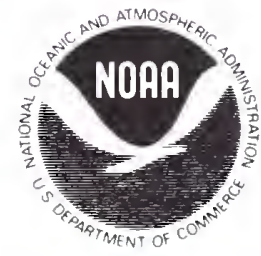




\section{FOREWORD}

This issue of the "Circulars" is part of a subseries entitled "Marine Flora and Fauna of the Northeastern United States." This subseries will consist of original, illustrated, modern manuals on the identification, classification, and general biology of the estuarine and coastal marine plants and animals of the northeastern United States. Manuals will be published at irregular intervals on as many taxa of the region as there are specialists willing to collaborate in their preparation.

The manuals are an outgrowth of the widely used "Keys to Marine Invertebrates of the Woods Hole Region," edited by R. I. Smith, published in 1964, and produced under the auspices of the Systematics-Ecology Program, Marine Biological Laboratory, Woods Hole, Mass. Instead of revising the "Woods Hole Keys," the staff of the Systematics-Ecology Program decided to expand the geographic coverage and bathymetric range and produce the keys in an entirely new set of expanded publications.

The "Marine Flora and Fauna of the Northeastern United States" is being prepared in collaboration with systematic specialists in the United States and abroad. Each manual will be based primarily on recent and ongoing revisionary systematic research and a fresh examination of the plants and animals. Each major taxon, treated in a separate manual, will include an introduction, illustrated glossary, uniform originally illustrated keys, annotated check list with information when available on distribution, habitat, life history, and related biology, references to the major literature of the group, and a systematic index.

These manuals are intended for use by biology students, biologists, biological oceanographers, informed laymen, and others wishing to identify coastal organisms for this region. In many instances the manuals will serve as a guide to additional information about the species or the group.

Geographic coverage of the "Marine Flora and Fauna of the Northeastern United States" is planned to include organisms from the headwaters of estuaries seaward to approximately the $200-\mathrm{m}$ depth on the continental shelf from Maine to Virginia, but may vary somewhat with each major taxon and the interests of collaborators. Whenever possible representative specimens dealt with in the manuals will be deposited in reference collections of the Gray Museum, Marine Biological Laboratory. and other universities and research laboratories in the region.

After a sufficient number of manuals of related taxonomic groups have been published, the manuals will be revised, grouped, and issued as special volumes. These volumes will thus consist of compilations of individual manuals within phyla such as the Coelenterata, Arthropoda, and Mollusca, or of groups of phyla. 


\section{CONTENTS}

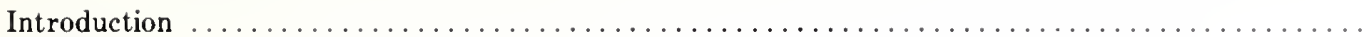

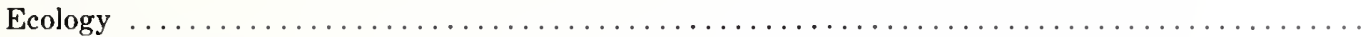

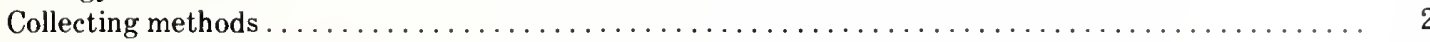

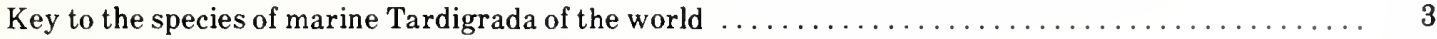

Annotated systematic list of marine Tardigrada of the world . . . . . . . . . . . . . . 21

List of marine Tardigrada reported from the northeastern United States . . . . . . . . . . . . . . 22

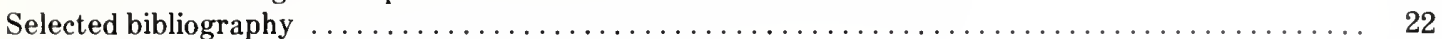

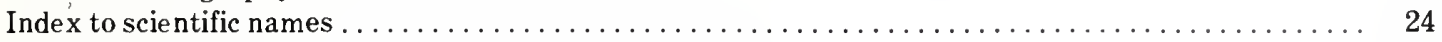

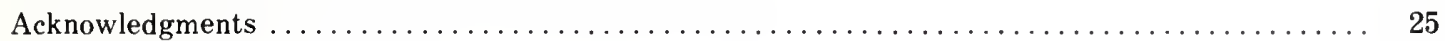

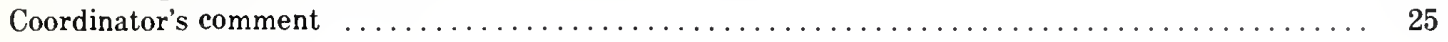

The National Marine Fisheries Service (NMFS) does not approve, recommend or endorse any proprietary product or proprietary material mentioned in this publication. No reference shall be made to NMFS, or to this publication furnished by NMFS, in any advertising or sales promotion which would indicate or imply that NMFS approves, recommends or endorses any proprietary product or proprietary material mentioned herein, or which has as its purpose an intent to cause directly or indirectly the advertised product to be used or purchased because of this NMFS publication. 
Digitized by the Internet Archive in 2013 


\title{
Marine Flora and Fauna of the Northeastern United States. Tardigrada
}

\author{
LELAND W. POLLOCK ${ }^{1}$
}

\begin{abstract}
The manual includes an introduction to the general biology, an illustrated key, an annotated systematic list, a selected bibliography, and an index to the Tardigrada of the marine coastal areas of the world to a depth of $5,000 \mathrm{~m}$.
\end{abstract}

\section{INTRODUCTION}

The Tardigrada (tardus, L. slow; gradus, L. step) comprise a phylum of microscopic metazoa (usually less than $1 \mathrm{~mm}$ in length) of uncertain phylogenetic placement. Considerations of their status have been based on 1) their growth by molting; 2) absence of ciliated epithelium; 3 ) presence of a spacious pseudocoelom in adults; 4) musculature in bandlike bundles; 5) metameric, or at least repetitive, arrangement of unjointed legs, as well as of portions of the ventral nervous system and muscular system; 6) the presence of coelomocytes; 7) the absence of circular muscles; 8) a tripartite foregut; 9) a nonchitinous cuticle; and 10) the occurrence of eutely or cell constancy (although this recently has been disputed, Bertolani 1970). Most of these characteristics suggest an organizational complexity approaching that of the aschelminth phyla, especially the Rotifera and Nematoda. Characters suggesting relationship with the Arthropoda include the first six characters listed above; in addition, their "ladder-type" ventral nervous sytem recalls the annelid-arthropod line. Tardigradan embryology however apparently includes a total but irregular cleavage pattern and enterocoelous formation of a series of coelomic pouches, of which only the gonocoel is retained in the adult. While this pattern of development is unlike any other known group, it is most similar to that of the deuterostomous invertebrates.

Lack of clarity regarding their phylogenetic affinities suggests that the Tardigrada are far removed from their nearest phyletic neighbor. Apparently they are an old group which has become highly specialized for life in peculiar habitats, such as the water films surrounding lower plants and lining interstitial spaces between grains of sand. Morphological diversity among marine tardigrades attests to their age. On the other hand, the comparative uniformity in appearance and simplicity in morphological characters of freshwater forms supports the hypothesis that marine tardigrades are primitive. There are 43 described species of marine tardigrades included in 17 genera. Most are members of the interstitial meiofauna of sandy sediments.

${ }^{1}$ Department of Zoology, Drew University, Madison, NJ 07940.
Since one-half of these are in mono- or ditypic genera, and two-thirds have been discovered since 1950 , it is likely that many more species will be described in the future.

Marine tardigrades rarely exceed $0.5 \mathrm{~mm}$ in length and are all similar in general body plan (Fig. 1). They possess as many as 11 cephalic appendages, including lateral cirri (a), clavae (cl), external cephalic cirri (ec), internal cephalic cirri (ic), and a median cephalic cirrus (mc). Their bodies usually are cylindrical, with four pairs of legs which terminate in claws, toes, or both. These terminal appendages, the spines or papillae on the legs, and the conformation of the caudal appendage (if present) are important taxonomically. Likewise, the presence and location of somatic cirri, especially posterior-lateral cirrus (e) (Fig. 1), can be of taxonomic significance. In the order Eutardigrada, the

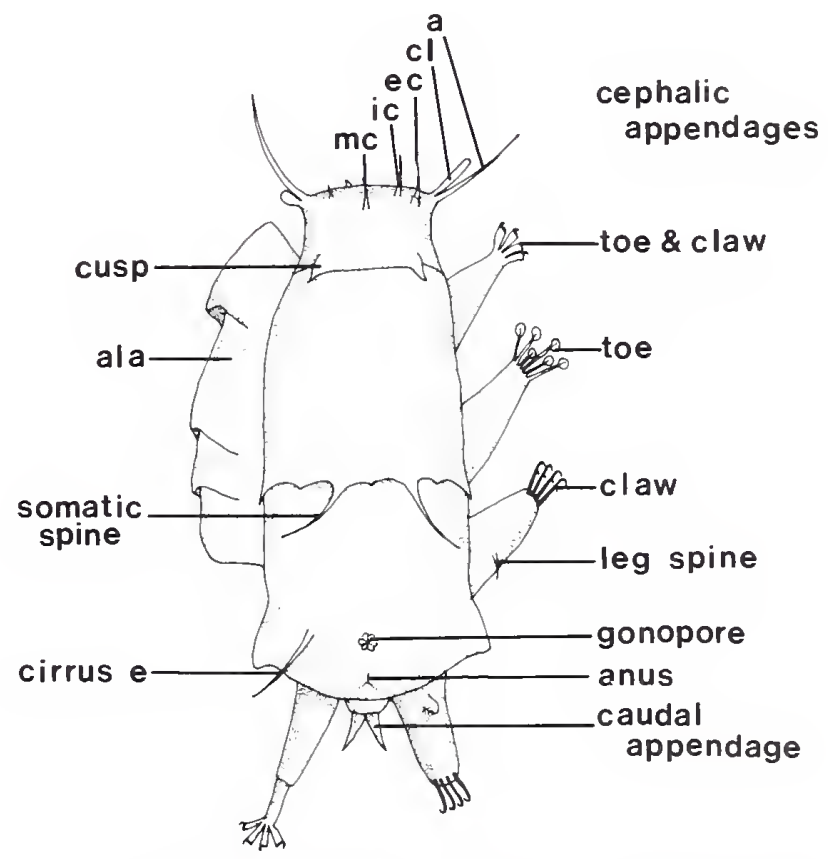

Figure 1. - Diagrammatic illustration of a composite marine tardigrade. Cephalic appendages: a - lateral cephalic cirrus; cl - clava; ec - external cephalic cirrus; ic - internal cephalic cirrus; mc - median cephalic cirrus. 
number and relative sizes of placoids or rod-shaped concretions within the bulbous muscular pharynx can be diagnostic.

Members of at least six genera (Archechiniscus, Batillipes, Coronarctus, Echiniscoides, Parastygarctus, and Stygarctus) display sexual dimorphism in the shape and location of gonopores. Females possess rosette gonopores located mid-ventrally at considerable distance anterior to the anus. In males, the gonopore is circular or tubular, mid-ventral and only slightly anterior to the anus. In members of the genus Halechiniscus, dimorphism is exhibited in the relation of the length of clavae relative to the lateral cirri. In males, clavae are longer than lateral cirri, while the opposite is true of females. Sex determination in other marine tardigrades is based on presence of mature gametes in the gonad or on the fact that males possess two vasa deferentia while females have a single oviduct.

Tardigrada develop directly. Excepting their disproportionately longer cephalic appendages and their reduced number of claws per leg, juveniles resemble miniature adults. Growth in Tardigrada is accomplished through periodic molting of all cuticular structures, including the linings of the foregut and hindgut. Apparently internal fluid pressure is reduced enough to permit defecation, oviposition, and sperm penetration only during an intermolt period.

Other aspects of the morphology and anatomy of marine tardigrades lie beyond the scope of this presentation. Interested readers are referred to monographs by Marcus (1936), Rudescu (1964), and Ramazzotti (1972), and to a recent review by Renaud-Mornant and Pollock (1971).

\section{ECOLOGY}

In recent years, ecological studies of marine Tardigrada have focused largely on those living interstitially among grains of sand (Renaud-Debyser 1959a; Schmidt 1968, 1969; Pollock 1970c; Lindgren 1971). Tardigrades are found throughout portions of intertidal beaches which undergo periodic drainage and replenishment of interstitial water. Most interstitial meiofauna, including tardigrades, are absent or uncommon in beaches of fine sand (mean grain diameter less than $300 \mu \mathrm{m}$ ) and in beaches of larger grainsize but where fine silt and debris clog pore spaces and restrict circulation.

Tardigrada occupy specific portions of littoral beaches creating patterns of zonation both horizontally along the beach surface and vertically within the sediment. A "typical pattern" of species composition and distribution on a single beach becomes evident from studies of temperate, quartz sand beaches. An abundant species and from one to several less common species of Batillipes occupy superficial sand (occurring somewhat deeper in beaches under the influence of heavy surf). The abundant Batillipes dominates mid-beach sand while other Batillipes often are relegated to more landward or seaward locations. A comparatively denser concentration of Stygarctus often occurs deeper within the beach approaching the deepest sediments undergoing tidal drainage of interstitial water.

Less frequently, marine tardigrades are reported from other habitats. Sublittoral specimens have been collected to a depth of $4,700 \mathrm{~m}$ (Renaud-Mornant 1974). Their comparative scarcity in most deepwater surveys suggests either that Tardigrada are less successful here than are many other meiofaunal groups or that sampling and/or observational techniques commonly used fail to include such small members of the meiofauna. Certain Tardigrada occur on seaweed ranging from intertidal Enteromorpha and Lichinia to offshore Sargassum. Among the several Tardigrada reportedly living ectocommensally with various other marine invertebrates, Tetrakentron synaptae Cuénot, 1892 alone possesses obvious morphological adaptations to such a life-style and has been found exclusively in such a relationship.

\section{COLLECTING METHODS}

A complete discussion of techniques for working with interstitial meiofauna generally and marine Tardigrada specifically may be found in Hulings and Gray (1971). Quantitative extraction of tardigrades from sand requires rigorous procedures since most species are strongly thigmotactic and vigorously resist dislodgment. Anesthetization by flooding a small sand sample with $3.5 \% \mathrm{MgCl}_{2}$ may be effective for removing Tardigrada from sediments gathered in areas of low to moderate wave activity; however, this technique is not effective quantitatively on samples from "high-energy" beaches (Gray and Rieger 1971). Soaking small quantities of sand (e.g., $10 \mathrm{~cm}^{3}$ or less) in 10 times that volume of $3.5 \%$ ethanol is more effective for anesthetization. This can be followed by three or more rinses of seawater to provide revived and apparently unharmed Tardigrada quantitatively.

Marine Tardigrada can be preserved well in either 5-7\% neutralized Formalin or in $70 \%$ ethanol. McGinty and Higgins (1968) described a widely used technique for mounting marine tardigrades. Specimens preserved in $7 \%$ Formalin are transferred to a 1:10 glycerin-Formalin solution which then is allowed to evaporate to glycerin (a glycerin-alcohol solution works for specimens preserved in alcohol). Tardigrades prepared by this technique can be mounted in glycerine, glycerine jelly, or Hoyer's medium. Phase contrast microscopy is necessary for fine observations, especially if Hoyer's medium is used. 


\section{KEY TO THE SPECIES OF MARINE TARDIGRADA OF THE WORLD}

The following key is designed for the artificial separation of marine tardigrades. Morphological characters are utilized for easy identification and are not intended to fully describe the animals. While examination of living animals at high power or oil immersion is imperative for complete and accurate descriptions, specimens fixed in $10 \%$ Formalin or $70 \%$ alcohol are usually recognizable. The illustrations are variously modified from original illustrations or descriptions. Important distinguishing features are indicated on each figure by short pointer lines.

Legs terminate in claws which attach directly, or if on toes are longer than toes $\ldots \ldots \ldots \ldots \ldots \ldots \ldots \ldots \ldots \ldots \ldots$

1 Legs terminate in toes without claws or with claws shorter than toes

2 (1) Central two claws on each leg bear hairlike extensions

2 (1) Claws without hairlike extensions

3 (2) Caudal spikes absent; anterior margin of head deeply sculptured

3 (2) Caudal spike present; anterior margin of head much less deeply sculptured

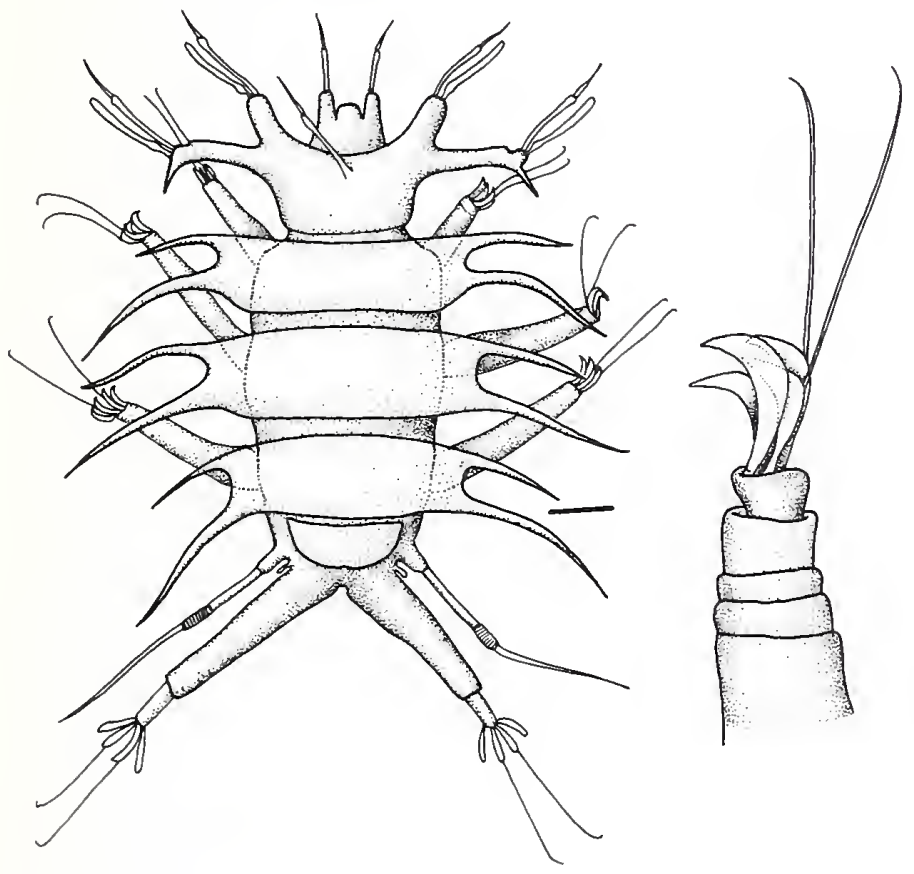

4 (3) Lateral extensions of dorsal plates end in single point.................Parastygarctus sterreri

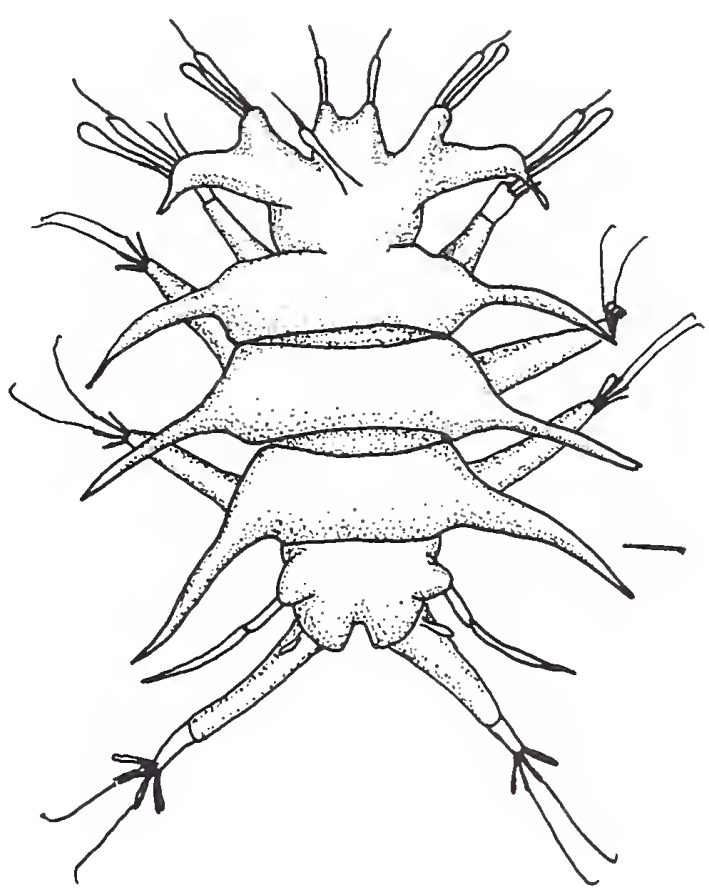




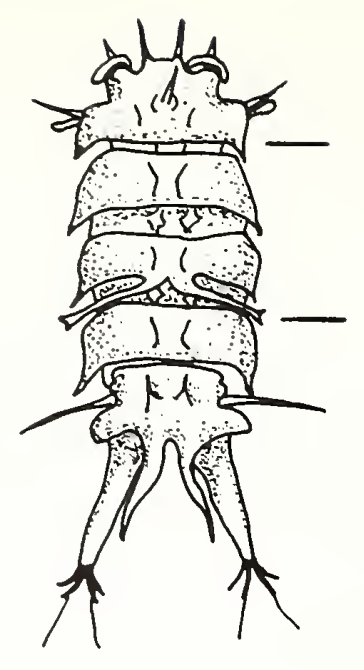

5 (3) Somatic spines on mid-posterior border of somatic plate II present; 2 cusps only along margin of cephalic plate...........Stygarctus bradypus

5 (3) Somatic spines on somatic plate II absent; 4 cusps along margin of cephalic plate .......Stygarctus granulatus

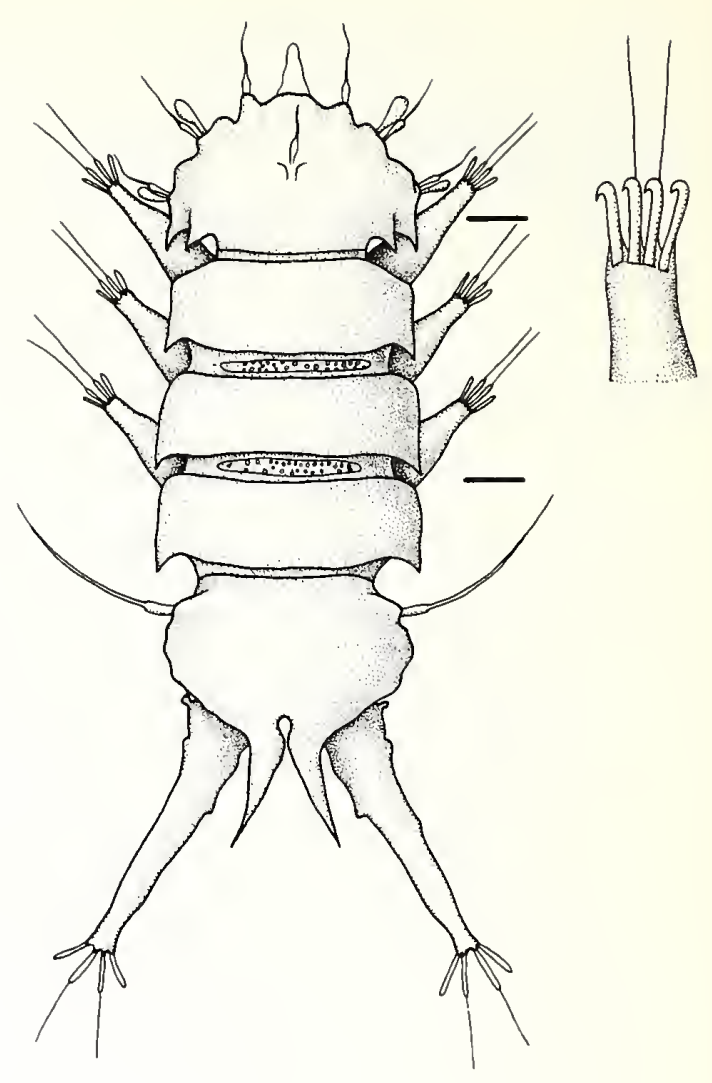

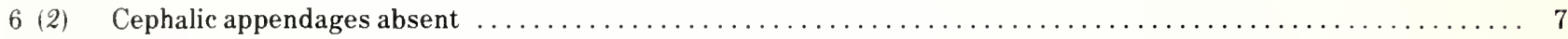

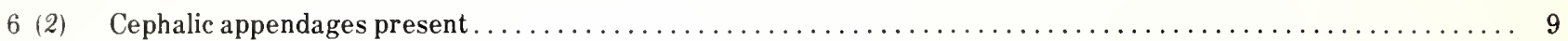

7 (6) First pharyngeal macroplacoid longer than second; inner diameter of pharyngeal tube $3 \mu \mathrm{m}$ 8
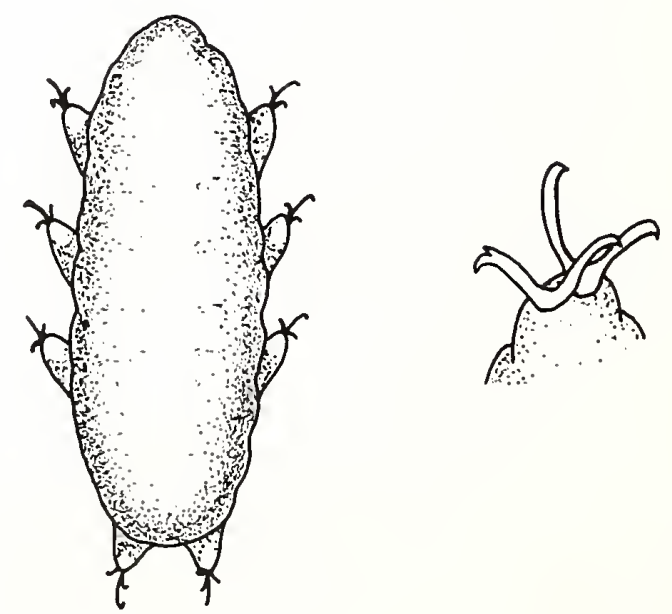

7 (6) First macroplacoid shorter than second; inner diameter of pharyngeal tube $1.5 \mu \mathrm{m}$

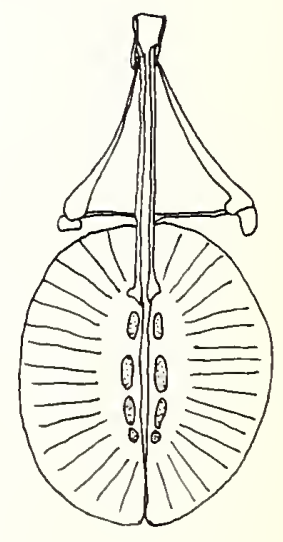




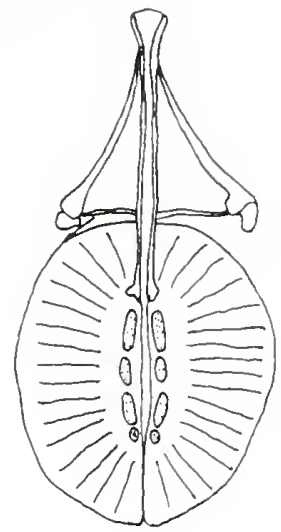

8 (7) Second macroplacoid as long as or longer than third Hypsibius geddesi

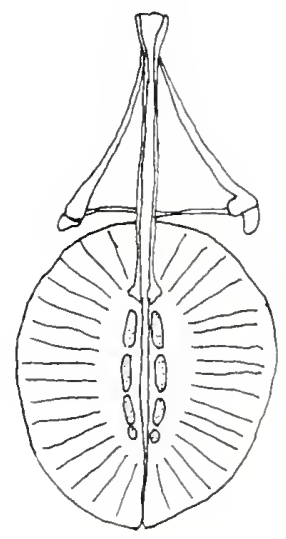

9 (6) More than four claws (usually 5-11) on each leg; distinct dorsal cuticular plates absent ........Echiniscoides sigismundi

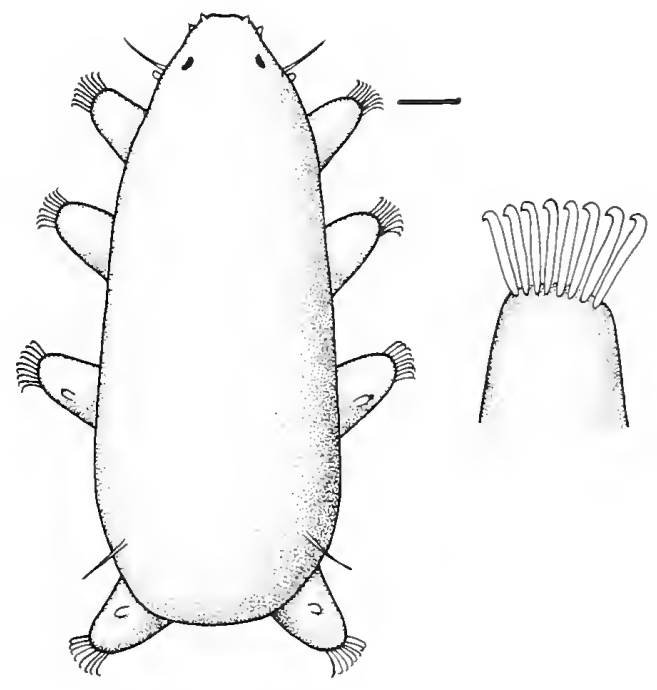

$9(6) \quad$ Four claws or less per leg 
10 (9) Four claws per leg present on anterior three pairs but only three claws per leg on posterior pair; distinct dorsal plates absent; median cirrus absent ... Anisonyches diakidius
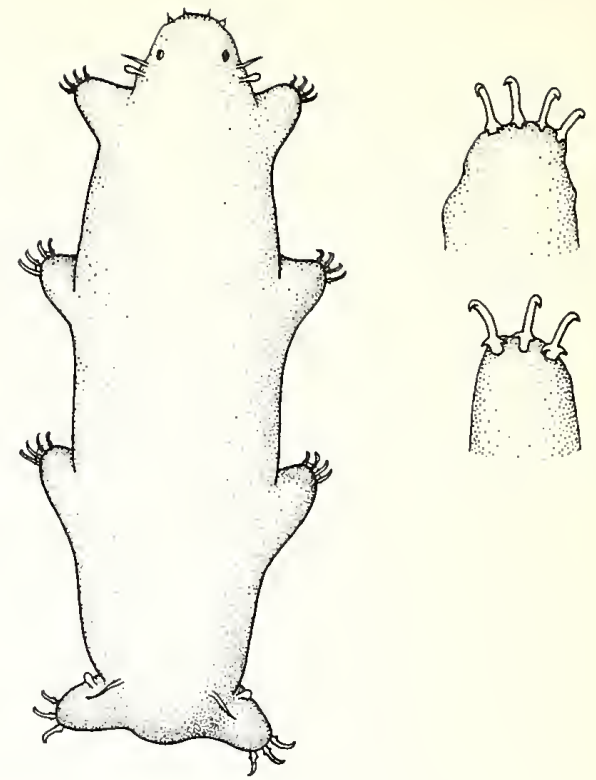

11 (10) Median cirrus present; distinct dorsal cuticular plates absent ...... Coronarctus tenellus

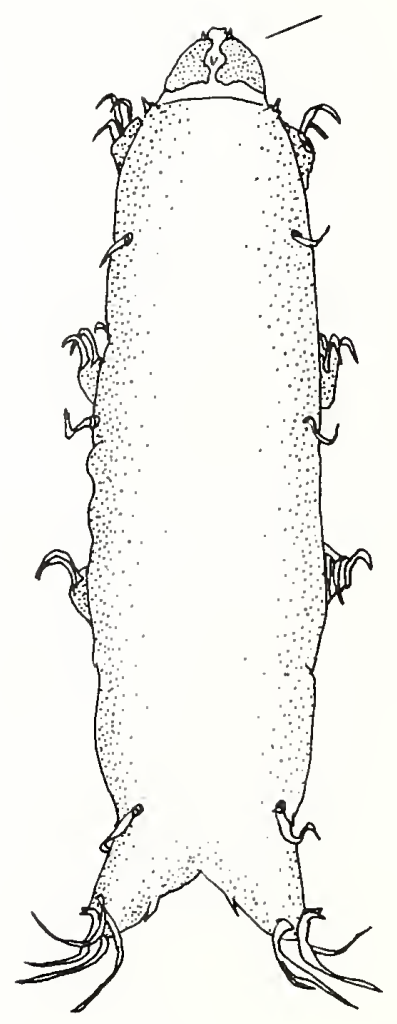

11 (10) Median cirrus absent; dorsal cuticular plates present ......... Echiniscus (E. quadrispinosus is the only species reported from marine environment.)

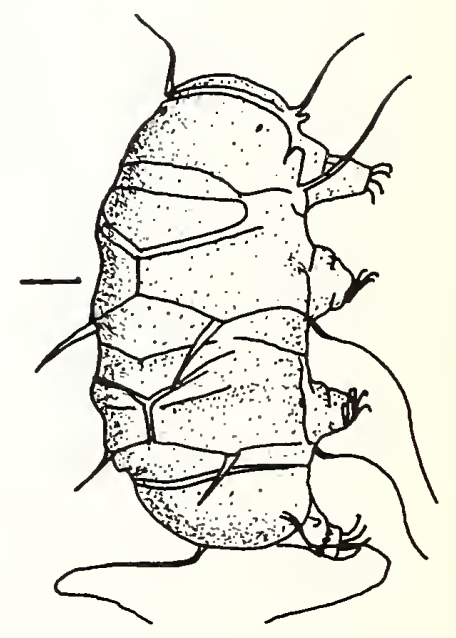


12 (1) Four to six toes without claws on each leg.

12 (1) Four toes with claws on each leg

13 (12) Toes end in disc expansions
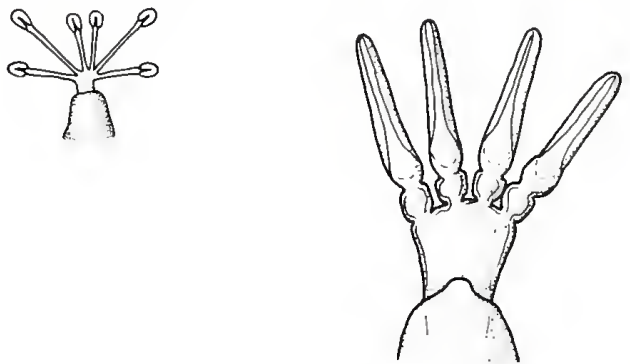

13 (12) Toes end in narrow lobate expansions

26

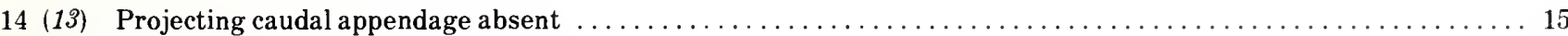

14 (13) Projecting caudal appendage present.

15 (14) Caudal end swollen cephalic appendages long ........... Batillipes tubernatis

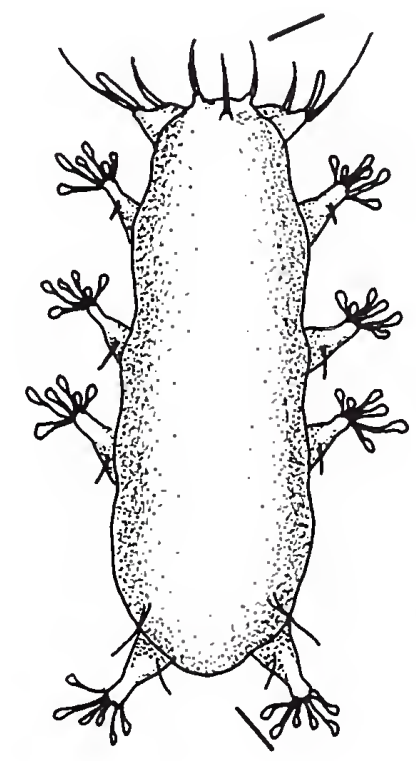

15 (14) Caudal end relatively flat; cephalic appendages short Batillipes acaudatus

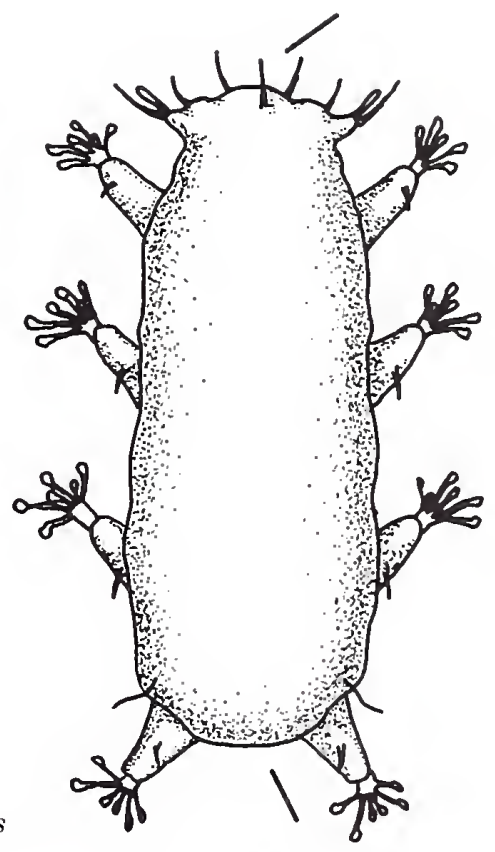


16 (14) Caudal appendage basically a single spike

16 (14) Caudal appendage more than one spike .

17 (16) Caudal spike terminates in a membranous bag

Batillipes bullacaudatus

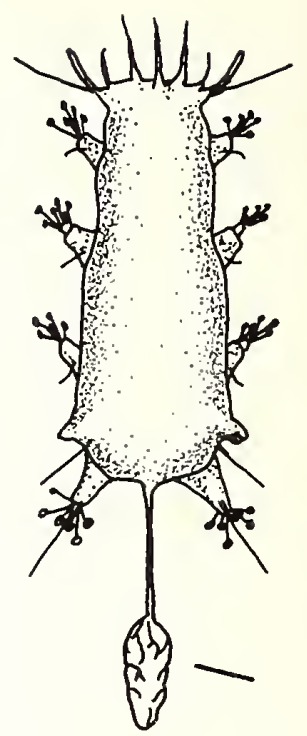

17 (16) Caudal spike blunt or sharp tipped

$18(17)$ Distinct constriction(s) present on clavae

19

$18(17)$ Clava uniform in width, constrictions absent

19 (18) More than one constriction present on clavae Batillipes annulatus

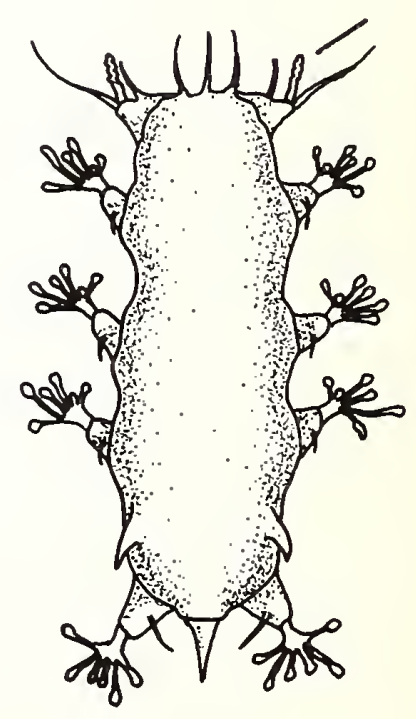




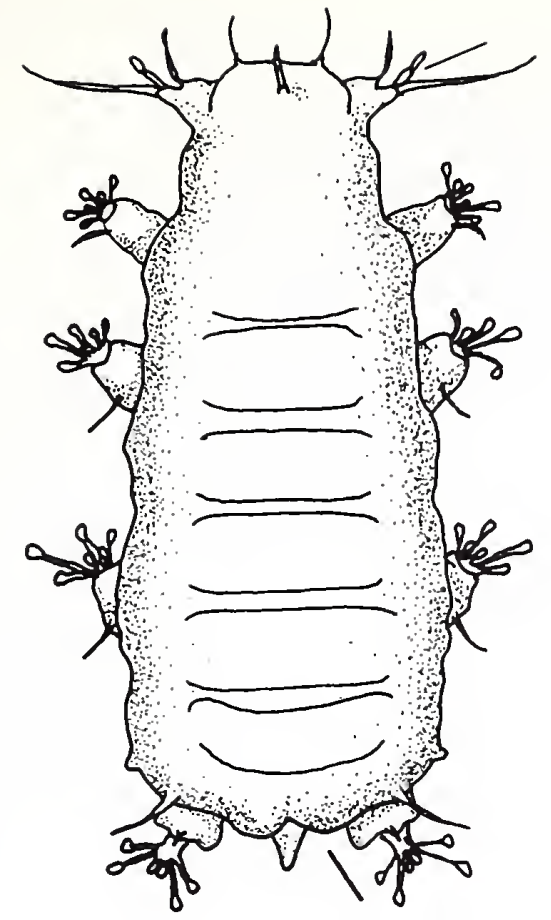

20 (19) Caudal spike from two-lobed base .... Batillipes gilmartini

20 (19) Caudal spike from single-lobed base Batillipes pennaki

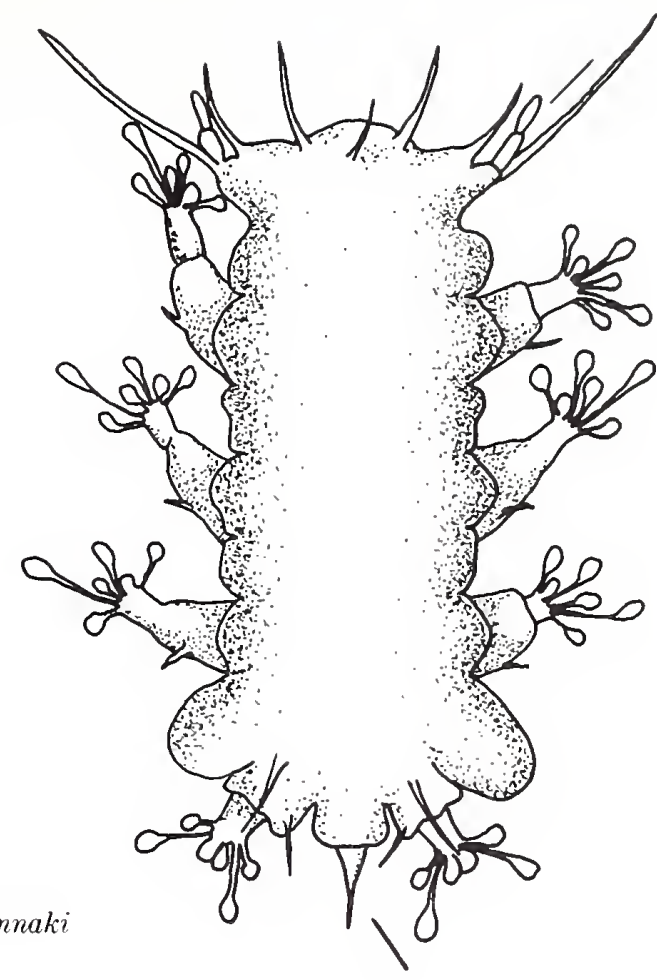

21 (18) Leg spines on hindmost legs short; leg spines present on anterior three pairs of legs $\ldots \ldots \ldots \ldots \ldots \ldots \ldots \ldots \ldots \ldots \ldots \ldots \ldots$ Batillipes mirus

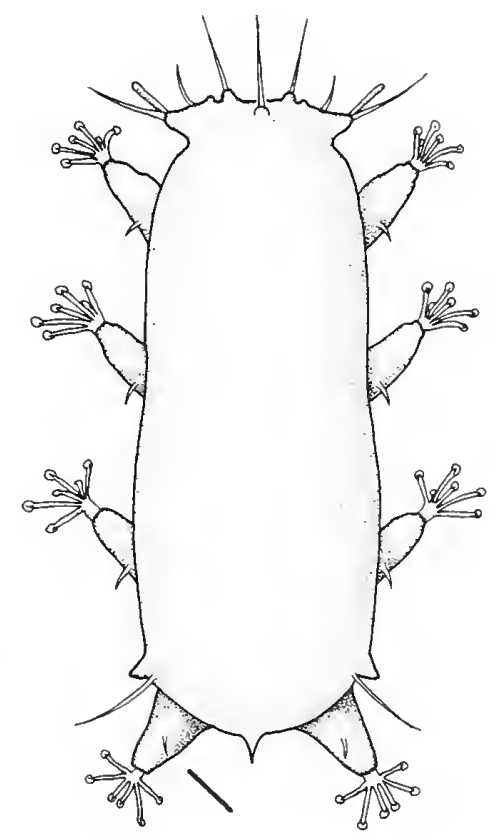

21 (18) Leg spines on hindmost legs long; spines absent on anterior three pairs of legs 


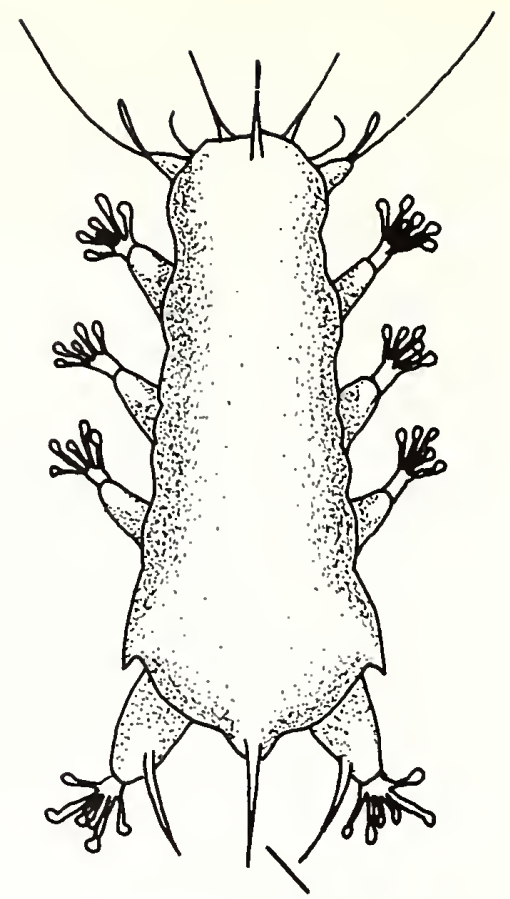

22 (21) Caudal appendage a long, slender, sharp-tipped spike .. Batillipes carnonensis

22 (21) Caudal appendage, a short, thick, blunt-tipped spike..........Batillipes similis

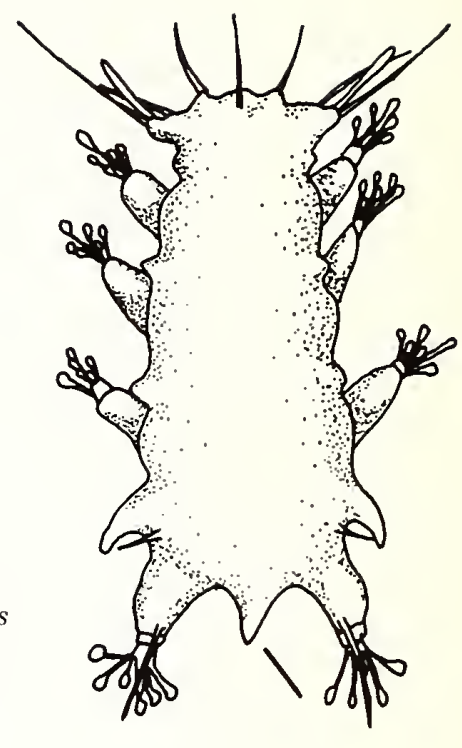

23 (16) Caudal appendage two-spiked Batillipes dicrocercus

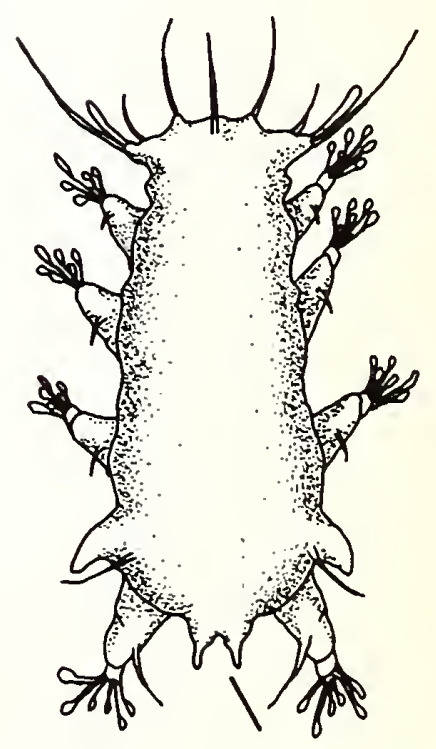

23 (16) Caudal appendage bears three or more spikes 
24 (23) Caudal appendage bears more than three spikes; central spike longest ....................... Batillipes phreaticus
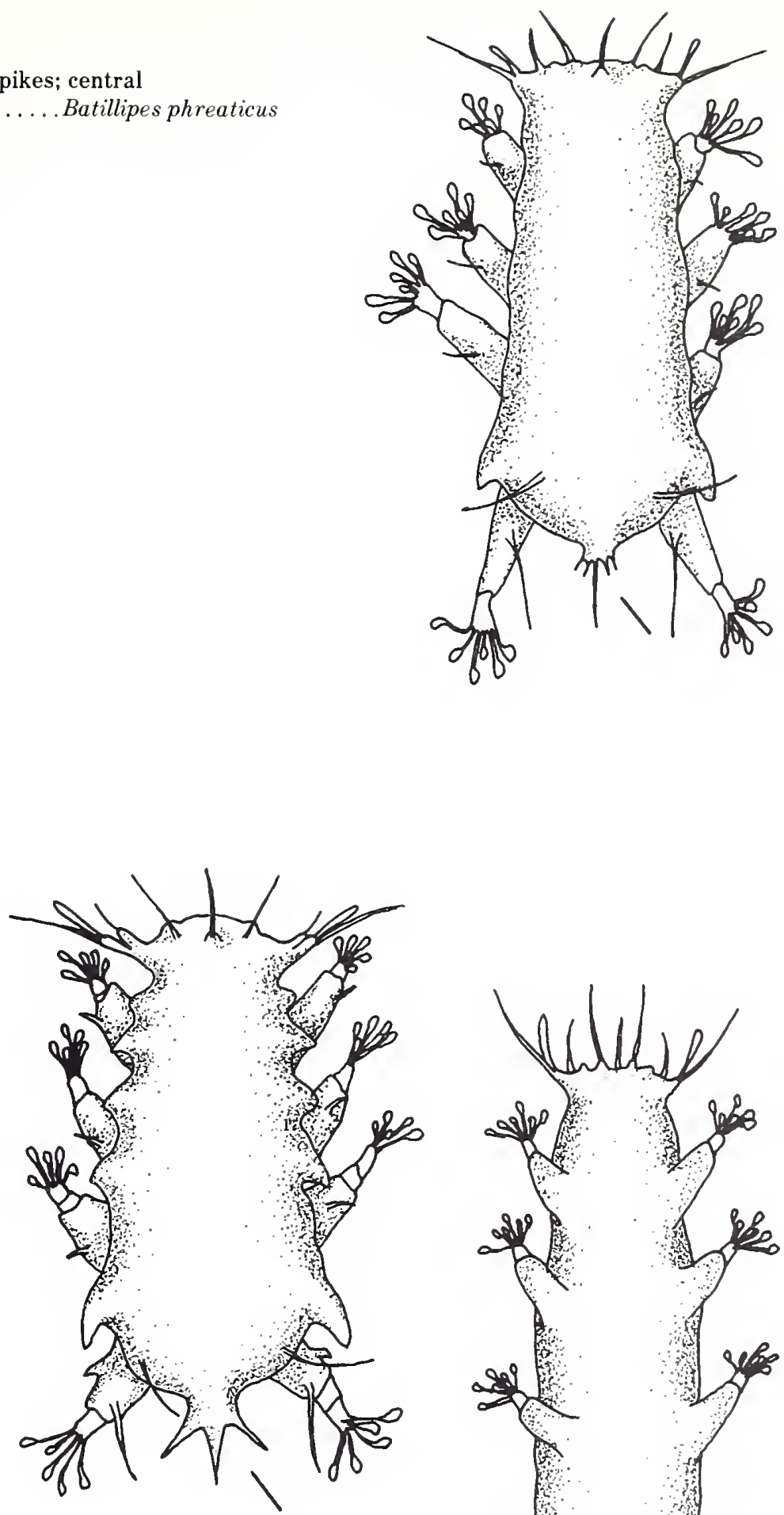

25 (24) Spikes of equal length Batillipes littoralis

25 (24) Lateral spikes shorter than central spike . Batillipes friaufi 


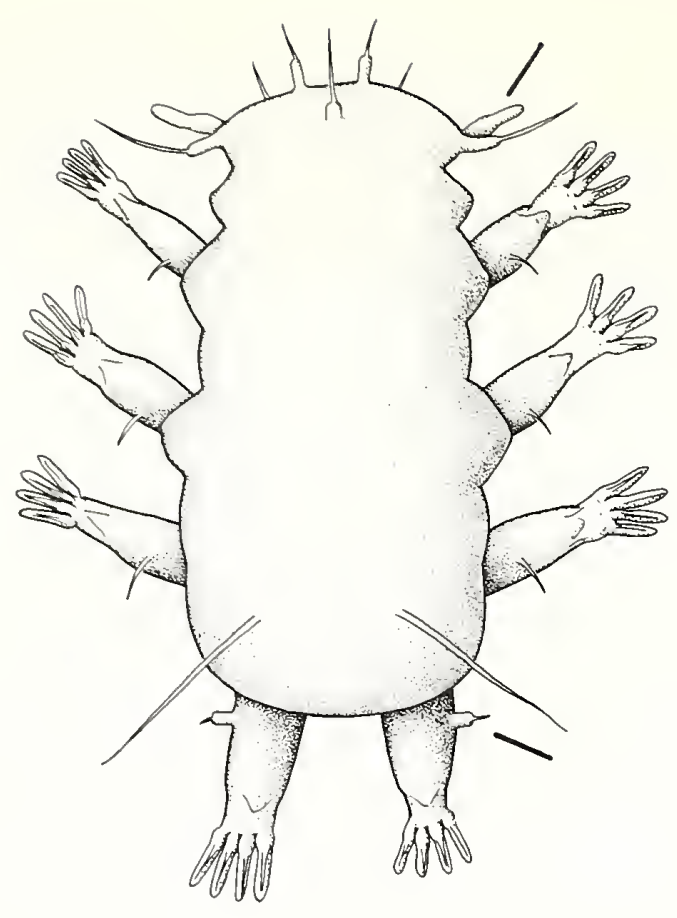

26 (13) Papilla present on fourth pair of legs; clava slightly constricted ............ Orzeliscus belopus

26 (13) Papilla absent on fourth pair of legs; clava uniform in width............ Orzeliscus septentrionalis
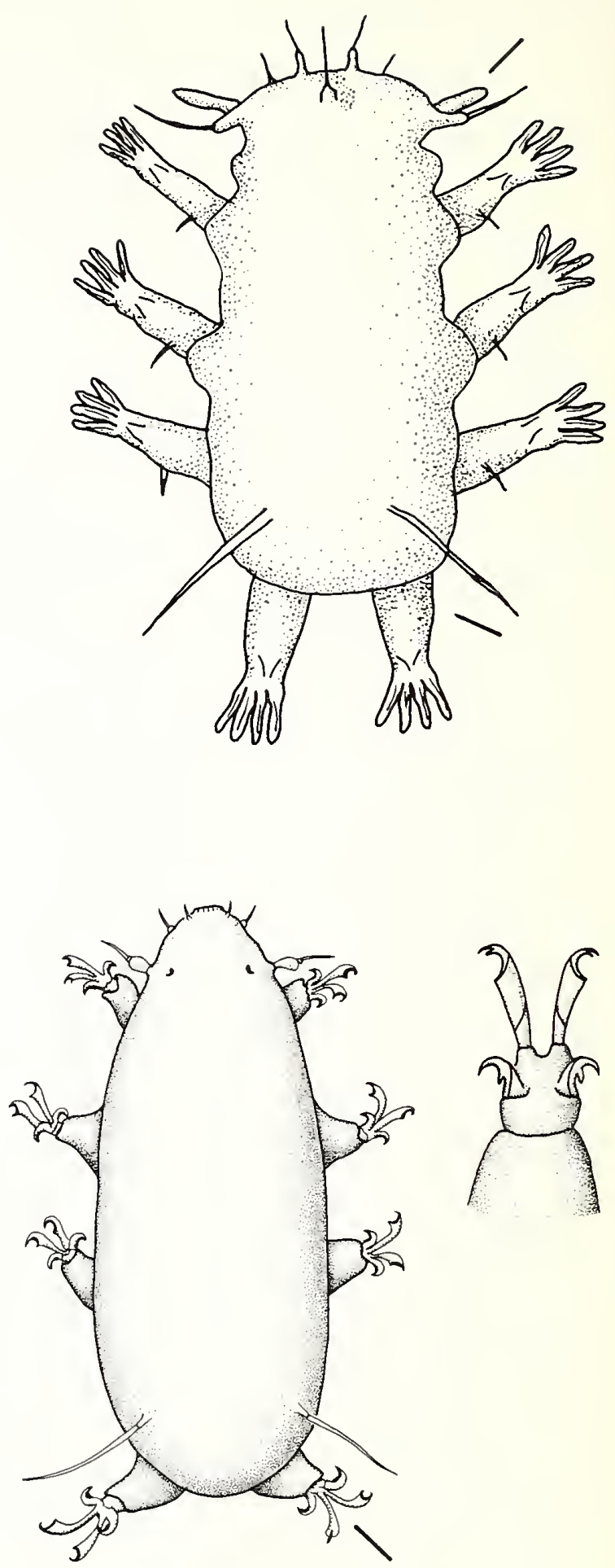

27 (12) Toes approximately equal in length 
29 (28) Body flattened dorsoventrally; cephalic appendages reduced; ectocommensal .. ....................Tetrakentron synaptae

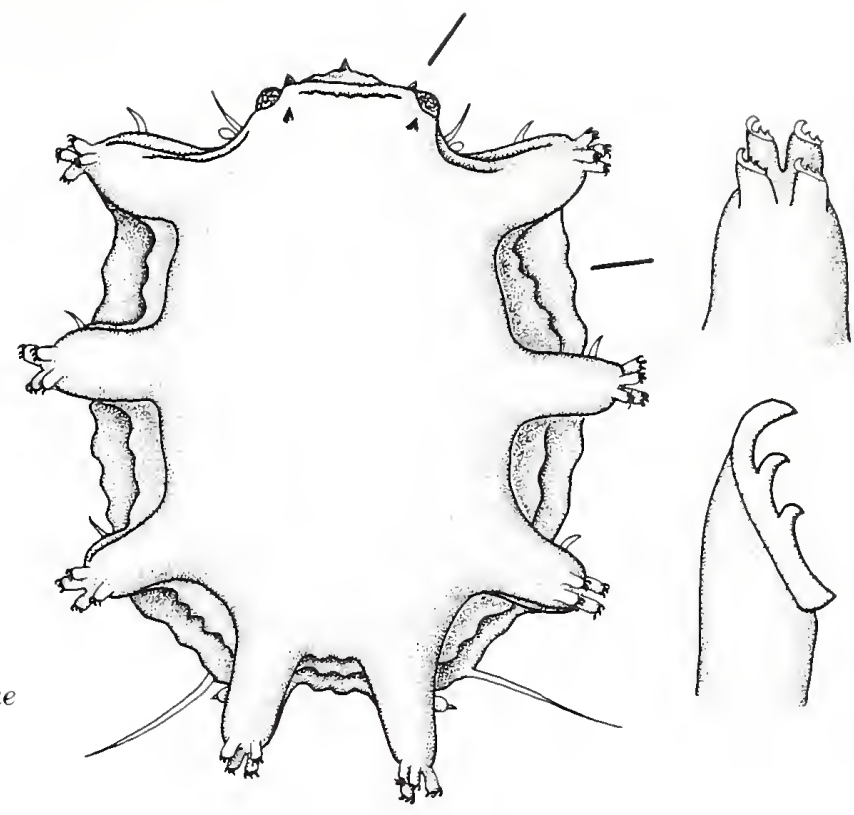

29 (28) Body cylindrical

30 (29) Each claw has four exposed points Bathyechiniscus tetronyx

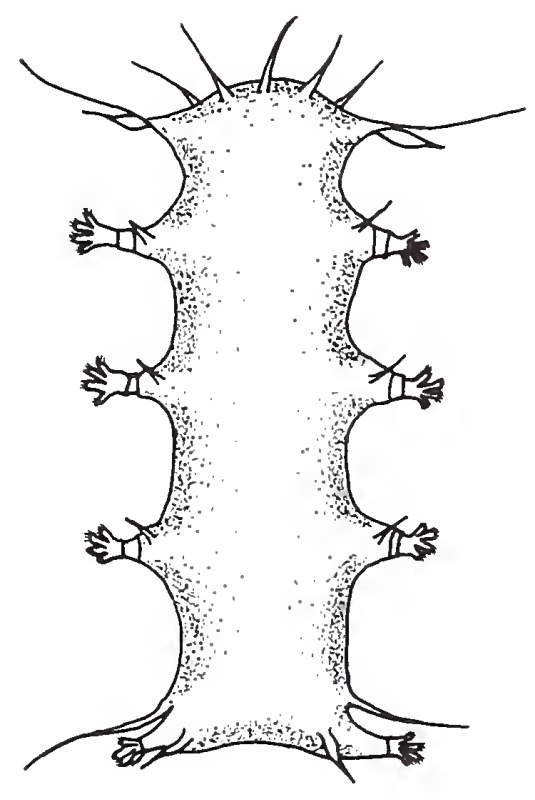


31 (30) Cirri e and clavae both absent Styraconyx haploceros
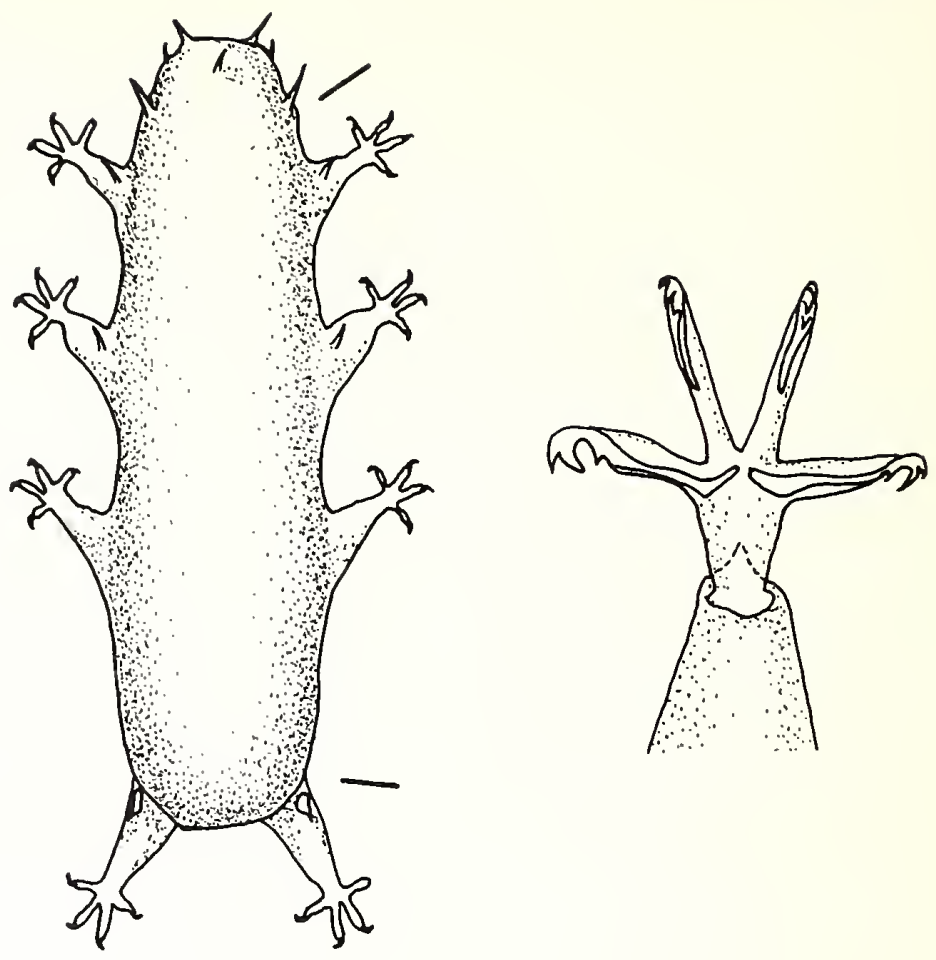

32 (31) Clavae long $(30 \mu \mathrm{m})$; eyes present Styraconyx paulae
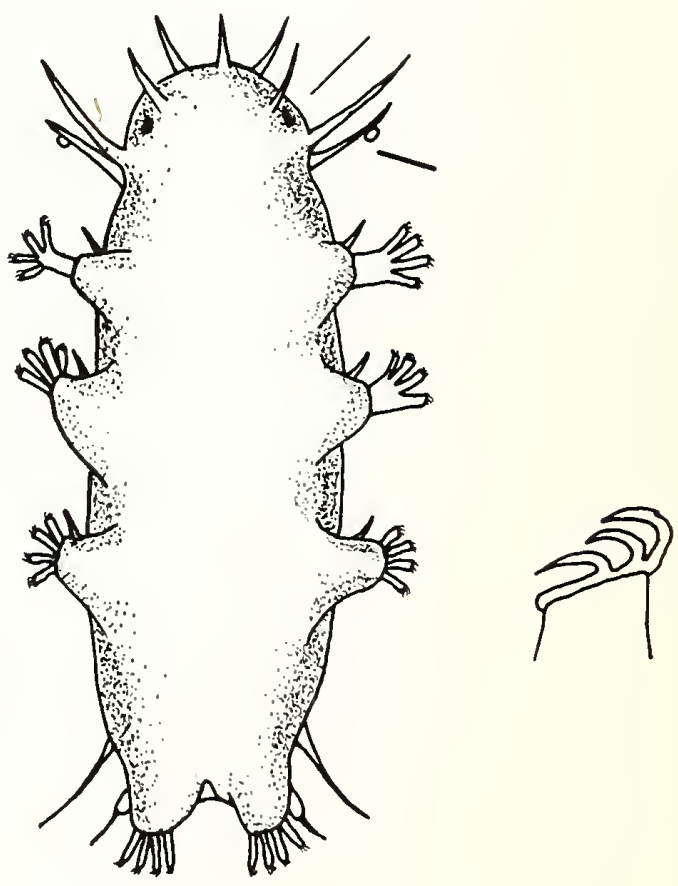


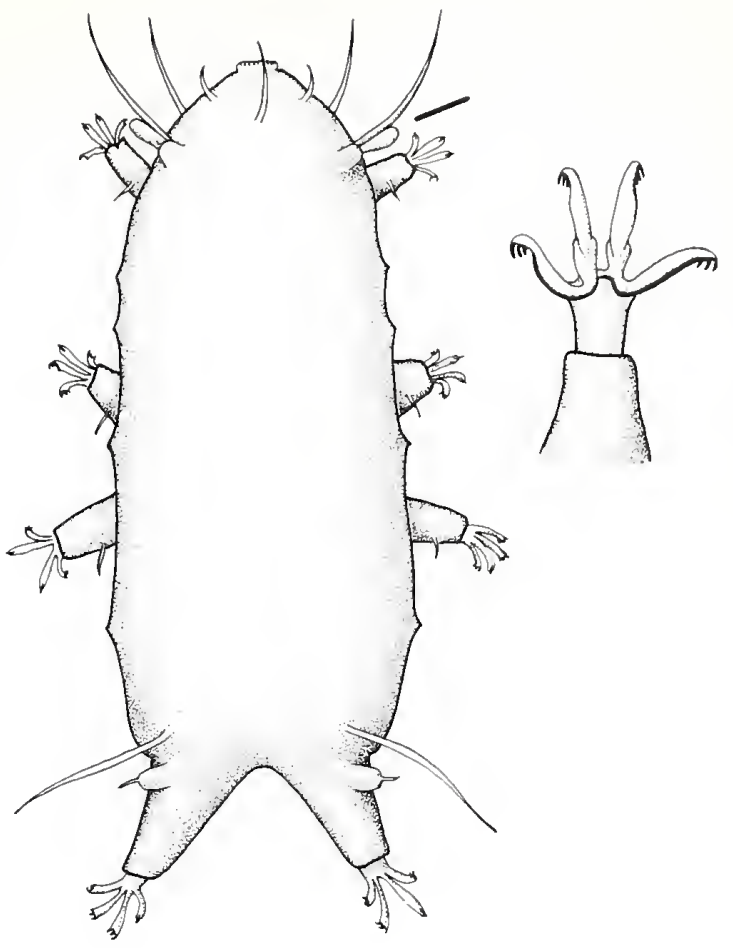

33 (28) Body covered dorsally by tubules and gelatinous coating ............... Actinarctus doryphorus

33 (28) Body smooth, lacking tubules and gelatinous coating 34

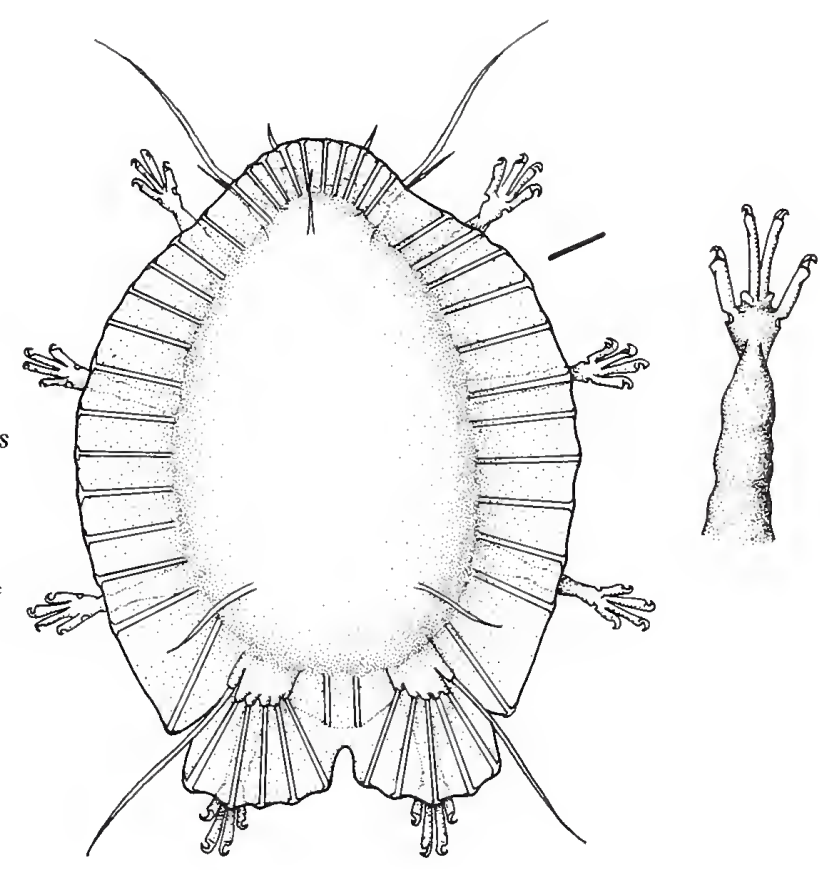

34 (33) Cuticle forms two caudal projections (branched or unbranched) extending more than body length 
35 (34) Caudal projections branched

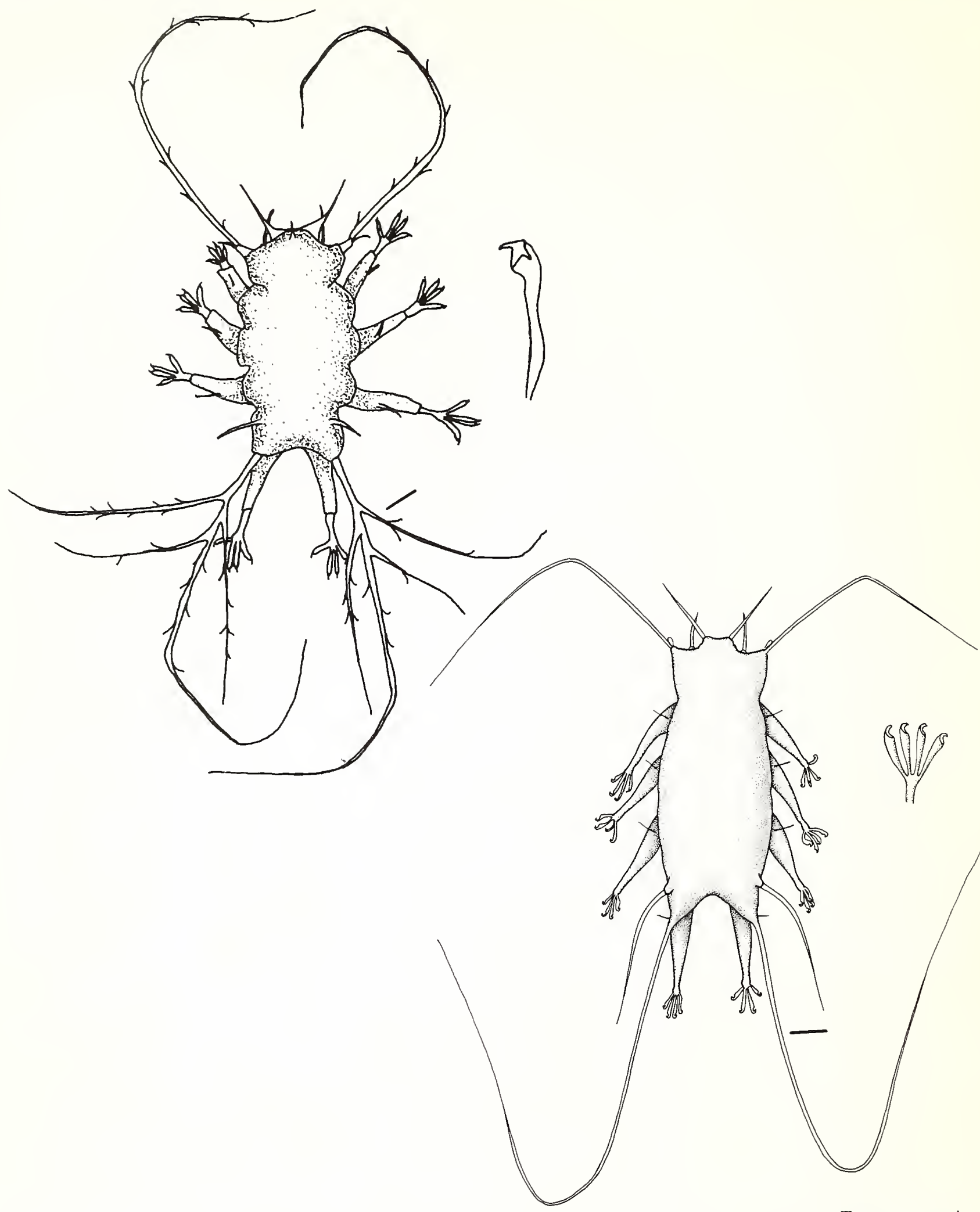

35 (34) Caudal projections unbranched

Tanarctus tauricus 
36 (34) Clava bulb-shaped; less than 0.5 length of lateral cirrus; eyes present Pleocola limnoriae

36 (34) Clava thin, more than 0.5 length of lateral cirrus; eyes absent

37 (36) All claws crescent shaped without "anchor spikes" 40

37 (36) Crescent shaped claws on middle two toes of each foot with accessory "anchor spike" embedded in toe

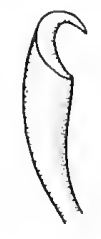
38
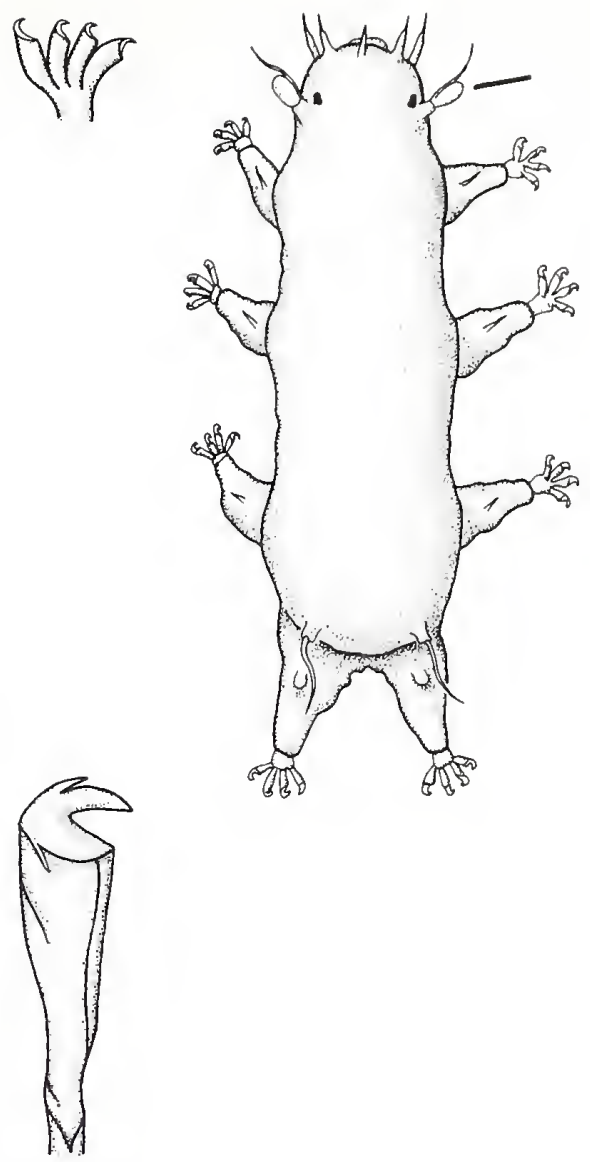

$38(37)$ Five peripheral alae or membranous sheets present$$
\text { .. }
$$$$
\cdots \cdots \cdots
$$
38 (37) Three peripheral alae present; caudal ala smooth, undivided; lateral alae undivided
.Florarctus salvati 39

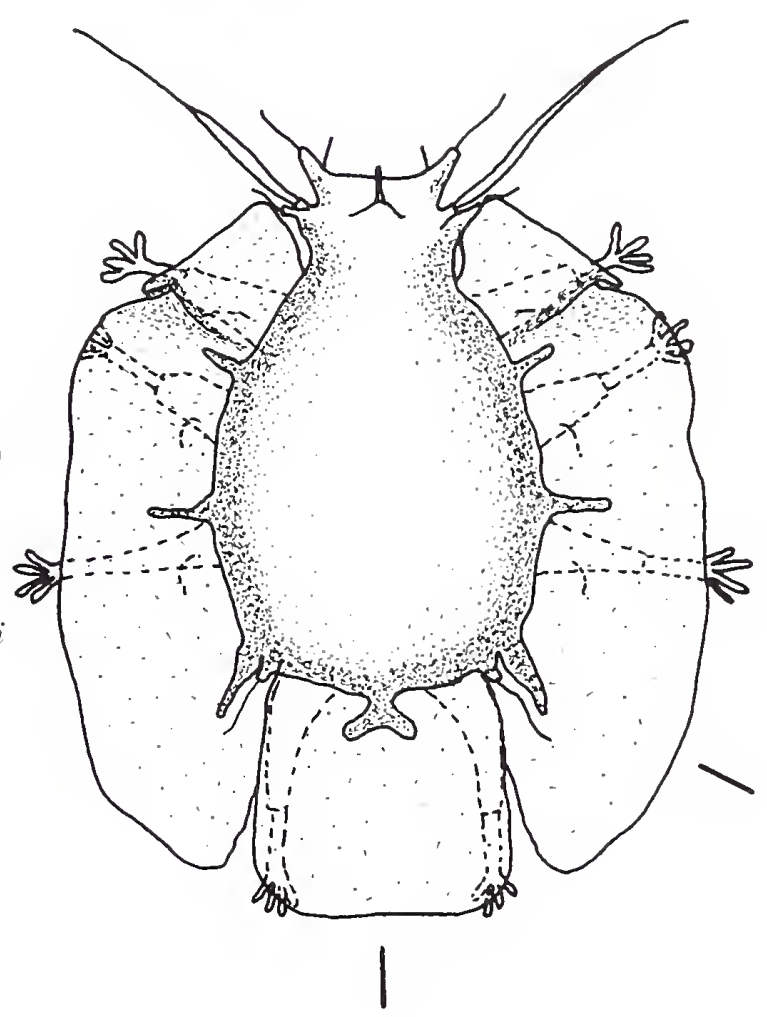



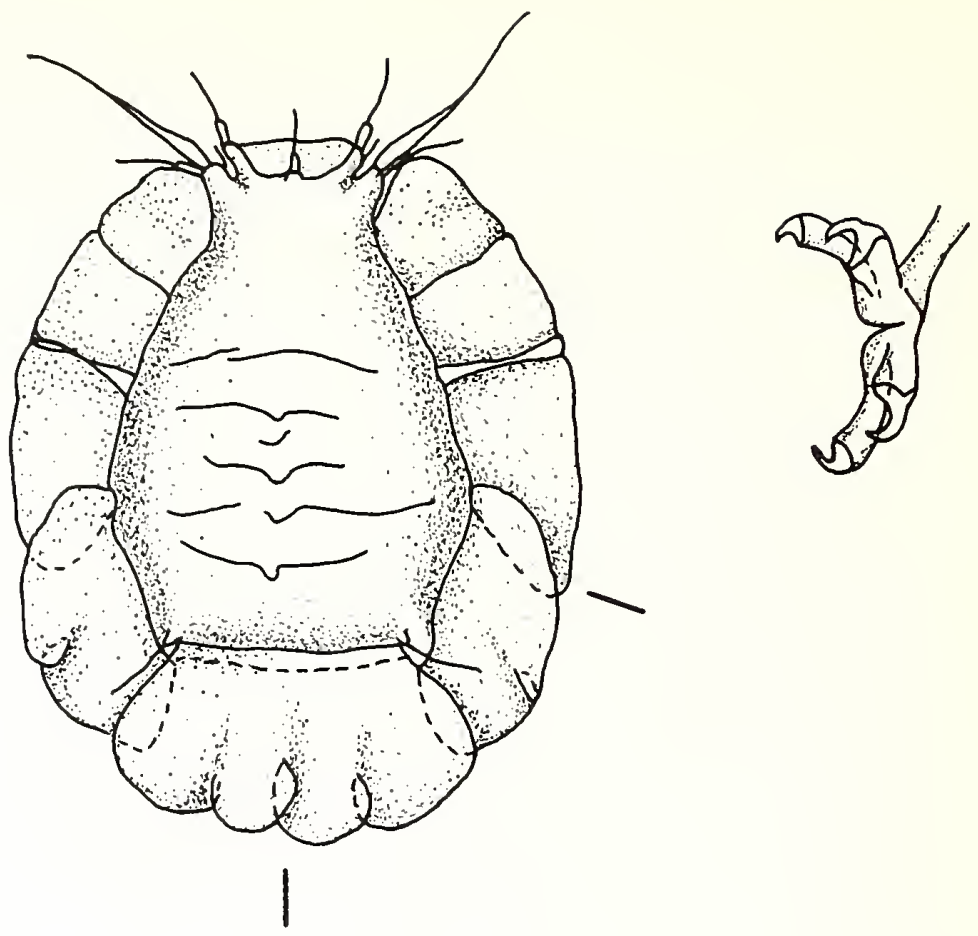

39 (38) Caudal ala deeply sculptured and nearly divided; lateral alae divided

Florarctus heimi

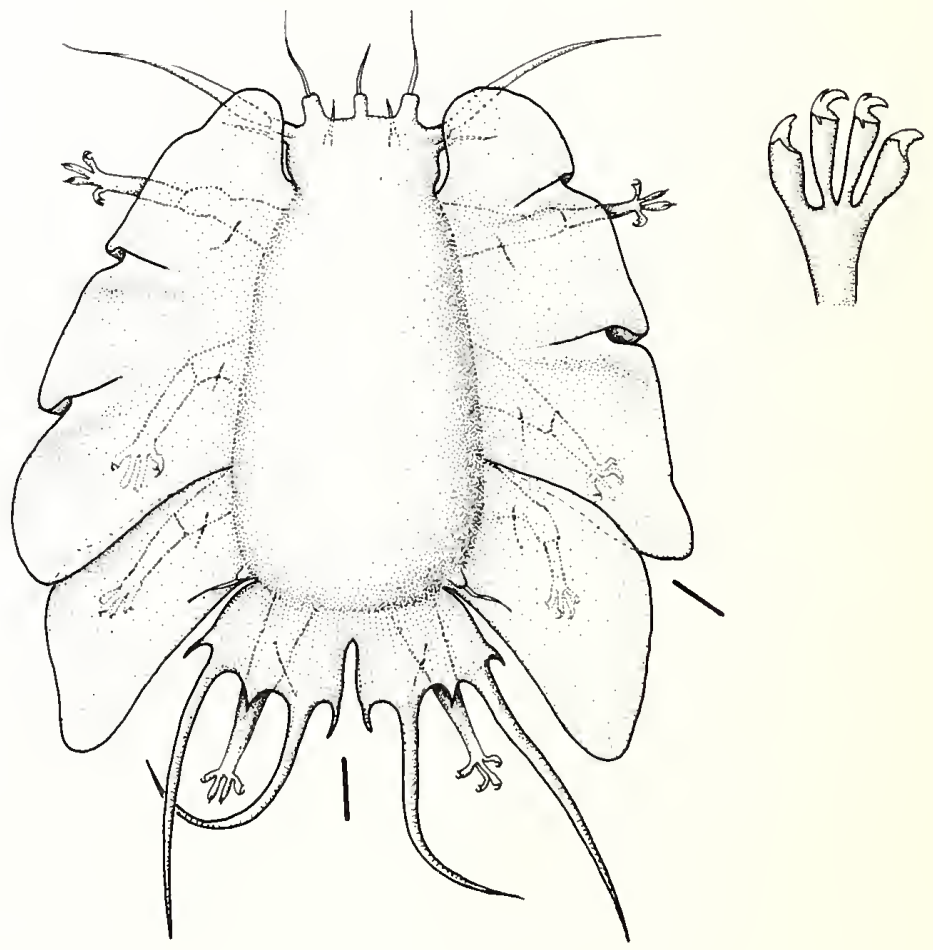


40 (37) Peripheral alae present

Halechiniscus intermedius
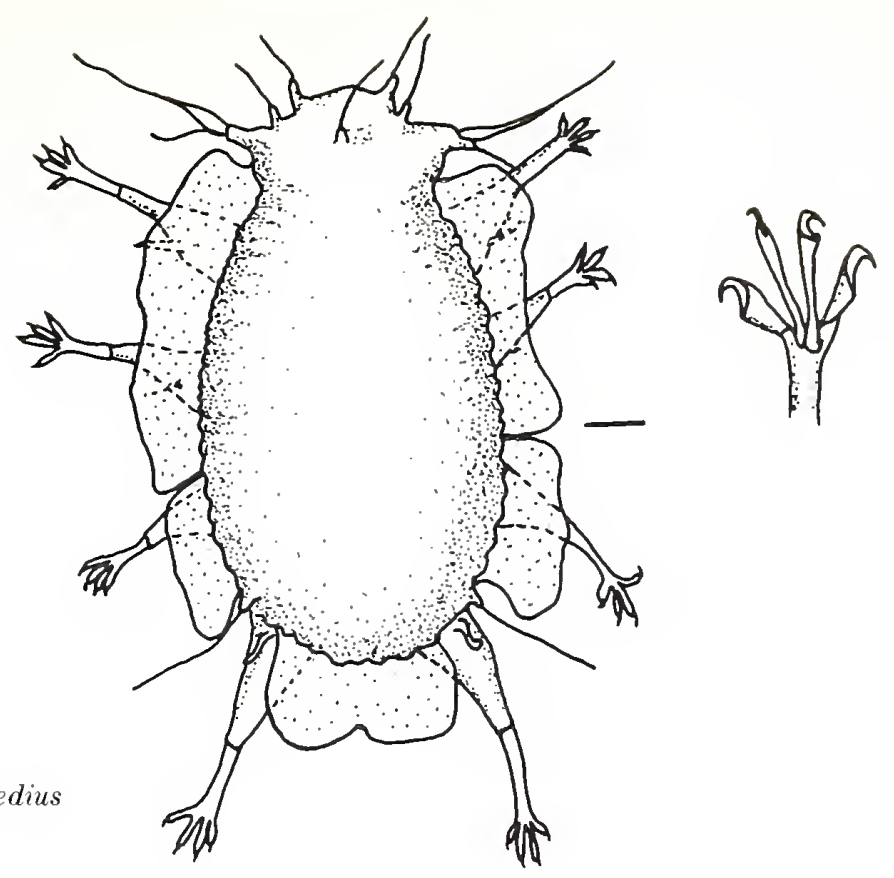

40 (37) Peripheral alae absent

41 (40) Caudal spike prominent

Halechiniscus remanei

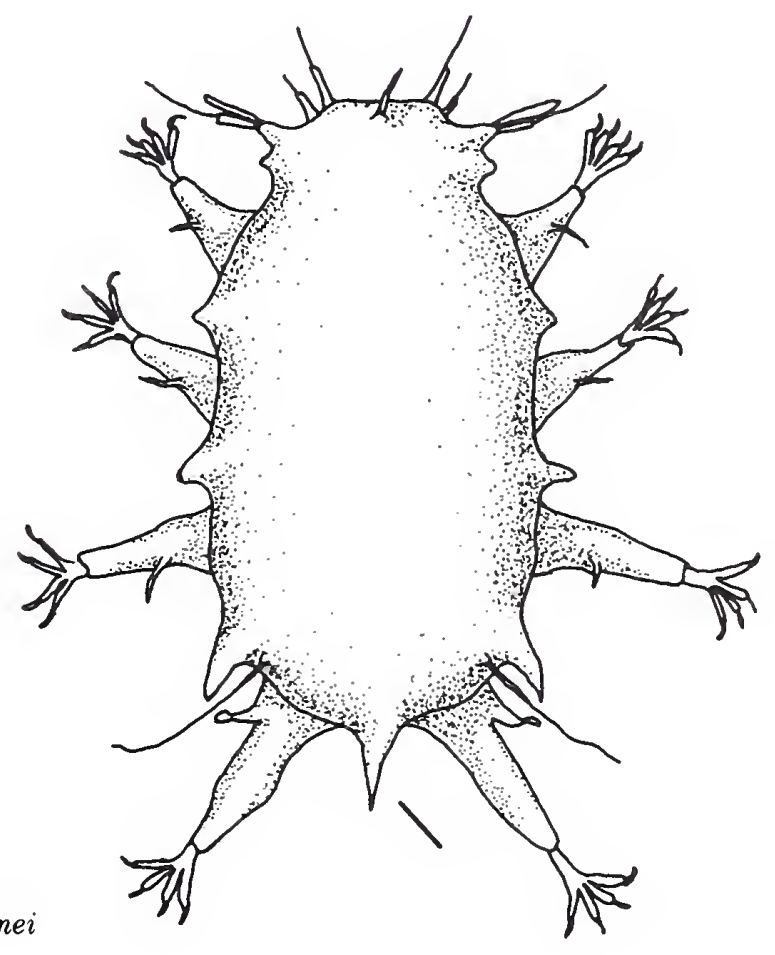

41 (40) Caudal spike absent 
42 (41) Cirri e present in addition to three pairs of somatic spines Halechiniscus guiteli

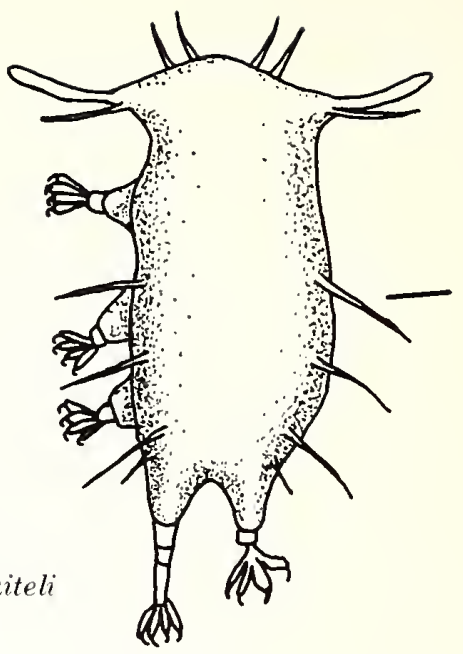

42 (41) Cirri e present but additional somatic spines absent
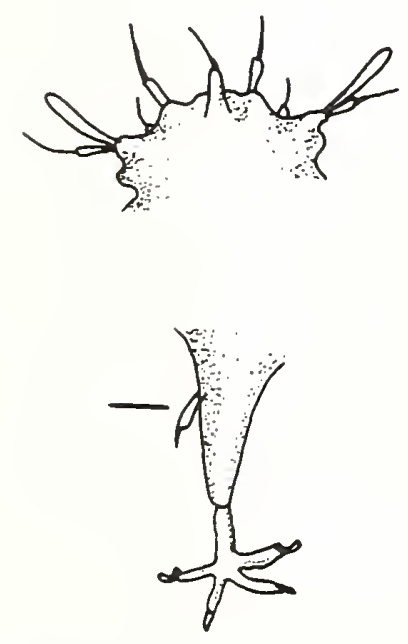
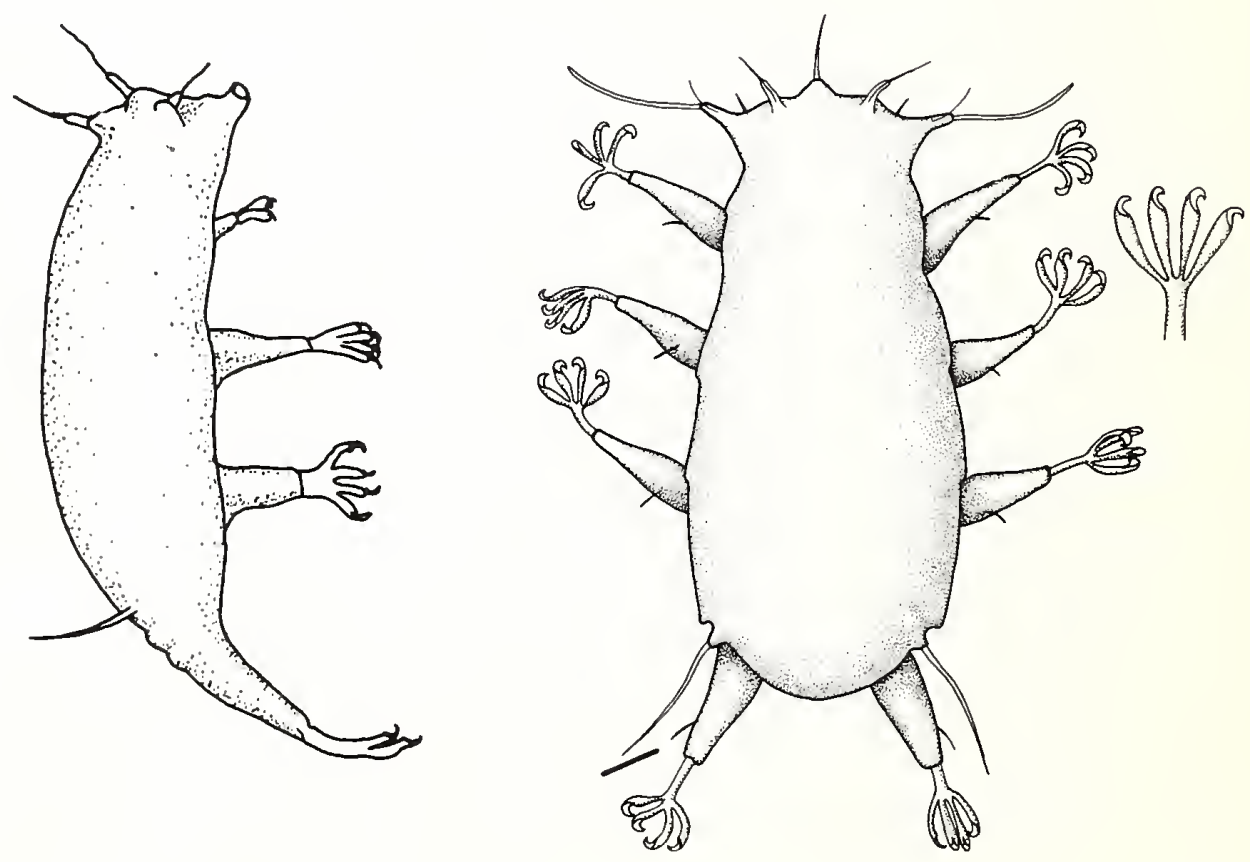

43 (42) Simple leg spine present on shank of hindmost legs; body with slight sequential ridges ... Halechiniscus subterraneus 


\section{ANNOTATED SYSTEMATIC LIST OF MARINE TARDIGRADA OF THE WORLD}

The arrangement of the following list is based on the classification suggested by Ramazzotti (1972). Original descriptions of all species are available through references in the bibliography. Where subsequent descriptions are useful, they are cited parenthetically. Finally, the most typical habitat and geographical range is indicated for each species.

\section{Order HETEROTARDIGRADA Suborder Arthrotardigrada FAMILY HALECHINISCIDAE}

Halechiniscus guiteli Richters 1908. Interstitial, sandy intertidal. English Channel, eastern Atlantic, Mediterranean, Black Sea.

Halechiniscus intermedius Renaud-Mornant 1967b. Interstitial, subtidal, coralline sand at $4 \mathrm{~m}$ depth. Southern Pacific.

Halechiniscus perfectus Schulz 1955 . Interstitial, sandy intertidal and subtidal at $170 \mathrm{~m}$ depth. North Sea, Mediterranean, southern Pacific, Indian Ocean.

Halechiniscus remanei Schulz 1955 (McGinty 1969). Interstitial, sandy intertidal to subtidal at $150 \mathrm{~m}$ depth. Mediterranean, eastern Atlantic, eastern Pacific.

Halechiniscus subterraneus Renaud-Debyser 1959b. Interstitial, intertidal in coralline sand. Western Atlantic.

Pleocola limnoriae Cantacuzène 1951. Commensal of isopod Limnoria lignorum and sandy intertidal to subtidal at $130 \mathrm{~m}$ depth. English Channel, western Atlantic.

Actinarctus doryphorus Schulz 1935 (Grell 1937). Interstitial, sandy intertidal to subtidal at $170 \mathrm{~m}$ depth. One report of possibly ectocommensal relationship with Echinocyamus pusillus (Grell 1937). North Sea, English Channel, eastern Atlantic.

Tetrakentron synaptae Cuénot 1892. Ectocommensal on tentacles of holothurian, Leptosynapta galliennei. English Channel.

Styraconyx haploceros Thulin 1942. Lichens near high tidal line. English Channel.

Styraconyx paulae Robotti 1971. Shallow subtidal, epizoic on coral.

Styraconyx sargassi Thulin 1942. Pelagic on algae, especially Sargassum. Western Atlantic, Mediterranean, Gulf of Mexico, eastern Pacific.

Bathyechiniscus tetronyx Steiner 1926. Questionable description based on single observation from mud at $400 \mathrm{~m}$ depth in south Atlantic.

Florarctus antillensis Van der Land 1968 (Renaud-Mornant 1971). Interstitial in coralline sand, $3 \mathrm{~m}$ depth. Caribbean.

Florarctus heimi Delamare Deboutteville and RenaudMornant 1965 (Delamare Deboutteville and RenaudMornant 1966; Renaud-Mornant 1967b). Interstitial in coralline sand. Southern Pacific.

Florarctus salvati Delamare Deboutteville and RenaudMornant 1965 (Delamare Deboutteville and Renaud-
Mornant 1966; Renaud-Mornant 1967b). Interstitial in coralline sand. Southern Pacific.

Tanarctus arborspinosus Lindgren 1971. Interstitial, intertidal. Western Atlantic.

Tanarctus tauricus Renaud-Debyser 1959b. Interstitial, intertidal. Western Atlantic.

\section{FAMILY BATILLIPEDIDAE}

Batillipes acaudatus Pollock 1971. Interstitial, sandy intertidal. Northestern Atlantic.

Batillipes annulatus DeZio 1962. Interstitial, sandy intertidal. Mediterranean.

Batillipes bullacaudatus McGinty and Higgins 1968 (Pollock 1970a). Interstitial, sandy intertiday. Northwestern and western Atlantic.

Batillipes carnonensis Fize 1957. Interstitial, sandy intertidal. Mediterranean, Indian Ocean.

Batillipes dicrocercus Pollock 1970a. Interstitial, sandy intertidal. Northwestern Atlantic.

Batillipes friaufi Riggin 1962 . Interstitial, sandy intertidal. Western Atlantic.

Batillipes gilmartini McGinty 1969. Interstitial, sandy intertidal. Eastern Pacific.

Batillipes littoralis Renaud-Debyser 1959a. Sandy intertidal, interstitial. Eastern Atlantic.

Batillipes mirus Richters 1909 (Marcus 1927; Rudescu 1964; McGinty and Higgins 1968; Pollock 1970a, b). Sandy intertidal and shallow subtidal, interstitial. Baltic, North Sea, Black Sea, Mediterranean, Atlantic, Indian Ocean.

Batillipes pennaki Marcus 1946 (DeZio 1962; Pollock 1970a, b). Interstitial, sandy intertidal. Northern and southern Atlantic, Mediterranean, Indian Ocean.

Batillipes phreaticus Renaud-Debyser 1959a (Riemann 1966; Pollock 1971). Intertidal, interstitial in sand. Northeastern Atlantic, North Sea.

Batillipes similis Schulz 1955 . Sandy intertidal, interstitial. Mediterranean.

Batillipes tubernatis Pollock 1971 (Riemann 1966). Sandy intertidal, shallow subtidal. North Sea, northeastern Atlantic.

Orzeliscus belopus Bois-Reymond Marcus 1952 (RenaudMornant 1967b). Interstitial in sand, intertidal and shallow subtidal. Northeastern, western, and southwestern Atlantic.

Orzeliscus septentrionalis Schulz 1953b. Interstitial in sand, intertidal. North Sea.

\section{FAMILY CORONARCTIDAE}

Coronarctus tenellus Renaud-Mornant 1974. Abyssal mud. Southern Atlantic, Indian Ocean.

\section{FAMILY STYGARCTIDAE}

Stygarctus bradypus Schulz 1951 (Renaud-Mornant and Anselme-Moizan 1969). Interstitial, intertidal. North Sea, northwestern and northeastern Atlantic, southern Pacific

Stygarctus granulatus Pollock 1970a (Pollock 1970b). Interstitial, intertidal. Northwestern Atlantic. 
Parastygarctus higginsi Renaud-Debyser 1965a (RenaudDebyser 1965b; Renaud-Mornant 1967a). Interstitial, intertidal. Southwestern and northeastern Indian.

Parastygarctus sterreri Renaud-Mornant, 1970. Sandy interstitial. Mediterranean, western Atlantic.

\section{Suborder Echiniscoidea}

\section{FAMILY OREELLIDAE}

Echiniscoides sigismundi (Schultze 1865) (Marcus 1927: Rudescu 1964: Pollock 1975). Intertidal on green and blue-green algae growing on barnacles, piers, seawalls, etc. Cosmopolitan.

Archechiniscus marci Schulz 1953a (Renaud-Mornant 1967b). Interstitial, sandy intertidal to shallow subtidal (18 m). Southern and eastern Pacific, Caribbean.

Anisonyches diakidius Pollock 1975. Interstitial in coralline sand. Western Atlantic, eastern Pacific.

\section{FAMILY ECHINISCIDAE}

Echiniscus quadrispinosus Richters 1902. A moss waterfilm species found in marine setting only once (RenaudDebyser 1964). Eastern Atlantic.

\section{Order EUTARDIGRADA}

\section{FAMILY MACROBIOTIDAE}

Hypsibius appelloefi (Richters 1908) (Hallas 1971). Intertidal. North Sea.

Hypsibius geddesi Hallas 1971. Intertidal, holdfast of Laminaria and interstitial in sand. Norwegian Sea, Kattegat.

Hypsibius stenostomus (Richters 1908) (Geddes 1968; Hallas 1971). Interstitial in sand or on brown algae. Baltic, North Sea, Black Sea.

\section{LIST OF MARINE TARDIGRADA REPORTED FROM THE NORTHEASTERN UNITED STATES}

Batillipes bullacaudatus - Woods Hole, Mass. (McGinty and Higgins 1968; Pollock 1970a).

Batillipes dicrocercus - Woods Hole, Mass. (Pollock 1970a).

Batillipes mirus - Woods Hole, Mass. (Marcus 1946; Pollock 1970a).

Batillipes pennaki - Woods Hole, Mass. (Marcus 1946; Pollock 1970a); Hampton Beach, Seabrook, N.H. (Pollock 1970a).

Echiniscoides sigismundi - Woods Hole, Mass. (McGinty and Higgins, 1968); Rye Harbor, Rye, N.H.; and Seawall Beach, Acadia National Park, Me. (Pollock, unpubl. paper).

Stygarctus granulatus - Woods Hole, Mass. (Uhlig 1968-as S. bradypus; McGinty and Higgins 1968-as S. bradypus; Pollock 1970a).

\section{SELECTED BIBLIOGRAPHY}

BERTOLANI, R.

1970. Mitosi somatiche e costanza cellulare numerica nei Tardigradi. Rend. Acc. Naz. Lincei, Ser. ${ }^{\mathrm{a}}$, 48:739-742.

BOIS-REYMOND MARCUS, E.

1952. On South American Malacopoda. Bol. Fac. Filos. Ciênc. Letras, Univ. Sao Paulo, Ser. Zool. 17:189-210.

CANTACUZĒNE. A.

1951. Tardigrade marin nouveau, commensal de Limnoria lig. norum (Rathke). C. R. Acad. Sci. Paris 232:1699-1700.

CUÉNOT, L.

1892. Tardigrade. In: Commensaux et parasites des Echinodermes (II). Rev. Biol. Nord. Fr. 5:16-19.

DELAMARE DEBOUTTEVILLE, C., and J. RENAUD-MORNANT. 1965. Un remarquable genre de Tardigrades des sables coralliens de Nouvelle-Calédonia. C. R. Acad. Sci. Paris 260:2581-2583.

1966. Un nouveau genre de Tardigrades des sables détritiques coralliens de Nouvelle-Calédonie. Cah. Pac. 9:149-156.

DeZIO, S

1962. Descrizione de Batillipes annulatus, n. sp. e note su Batillipes pennaki Marcus, nuovo rinvenimento nel Mediterraneo (Heterotardigrada). Annu. Ist. Mus. Zool. Univ. Napoli 14:1-7.

FIZE, A.

1957. Description d'une espèce nouvelle de Tardigrade Batillipes carnonensis n. sp. Bull. Soc. Zool. Fr. 82:430-433.

GEDDES, D. C.

1968. A note on the marine tardigrade Hypsibius (Isohypsibius) stenostomus (Richters) from the Troms $ø$ area, Northern Norway. Astarte 33:1-3.

GRAY, J. S., and R. M. RIEGER.

1971. A quantitative study of the meiofauna of an exposed sandy beach, at Robin Hood's Bay, Yorkshire. J. Mar. Biol. Assoc. U.K. 51:1-19.

GRELL, K. G.

1937. Beiträge zur Kenntnis von Actinarctus doryphorus E. Schulz nebst Bermerkungen zur Tardigradenfauna des Helgolidnder Skitt-Gatts. Zool. Anz. 117:143-154.

HALLAS, T.

1971. Notes on the marine Hypsibius stenostomus-complex, with a description of a new species (Tardigrada, Macrobiotidae). Steenstrupia 1:201-206.

HULINGS, N. C., and J. S. GRAY.

1971. A manual for the study of meiofauna. Smithson. Contrib. Zool. 78:1-84.

LINDGREN, E. W.

1971. Psammolittoral marine Tardigrades from North Carolina and their conformity to worldwide zonation patterns. Cah. Biol. Mar. 12:481-496.

MARCUS, E.

1927. Zur Anatomie und Ökologie mariner Tardigraden. Zool. Jahrb. Abt. Syst. Oekol. Geogr. Tiere 53:487-558.

1936. Tardigrada. Tierreich $66: 1-340$.

1946. Batillipes pennaki, a new marine Tardigrade from the north and south American Atlantic coast. Comun. Zool. Mus. Hist. Nat. Montev. 2:1-3.

MeGINTY, M. M.

1969. Batillipes gilmartini, a new marine tardigrade from a California beach. Pac. Sci. 23:394-396.

McGINTY, M. M., and R. P. HIGGINS.

1968. Ontogenetic variation of taxonomic characters of two marine tardigrades with the description of Batillipes bullacaudatus $\mathrm{n}$. $\mathrm{sp}$. Trans. Am. Microsc. Soc. 87:252-262.

POLLOCK, L. W.

1970a. Batillipes dicrocercus n. sp., Stygarctus granulatus n. sp. and other Tardigrada from Woods Hole, Massachusetts, USA. Trans. Am. Microsc. Soc. 89:38-52.

1970b. Reproductive anatomy of some marine Heterotardigrada. Trans. Am. Microsc. Soc. 89:308-316.

1970c. Distribution and dynamics of interstitial Tardigrada at Woods Hole, Massachusetts, U.S.A. Ophelia 7:145-165.

1971. On some British marine Tardigrada, including two new species of Batillipes. J. Mar. Biol. Assoc. U.K. 51:93-103. 
1975. Observations on marine Heterotardigrada, including a new genus from the western Atlantic Ocean. Cah. Biol. Mar. 16:121132.

RAMAZZOTTI, G.

1972. Il phylum Tardigrada. Mem. Ist. Ital. Idrobiol. 28:1-732.

RENAUD-DEBYSER, J.

1959a. Sur quelques Tardigrades du bassin d'Arcachon. Vie Milieu 10:135-146.

1959b. Études sur la faune interstitielle des Iles Bahamas. III. Tardigrades. Vie Milieu 10:296-302.

1964. Note sur la faune interstitielle du Bassin d'Arcachon et description d'un Gastrotriche nouveau. Cah. Biol. Mar. 5:111-123.

1965a. Parastygarctus higginsi n. g., n. sp. Tardigrade marin interstitiel de Madagascar. C. R. Acad. Sci. Paris 260:955-957.

1965b. Étude sur un Stygarctidé (Tardigrada) nouveau de Madagascar. Bull. Soc. Zool. Fr. 90:31-38.

RENAUD-MORNANT, J.

1967a. Parastygarctus higginsi Renaud-Debyser, 1965, sur la côte orientale de Malaisie. Description de la femelle. Bull. Mus. Natl. Hist. Nat., Paris 39:205-208.

1967b. Tardigrades de la Baie Saint-Vincent Nouvelle-Calédonie. Éditions de Fondat. Singer-Polignac, Paris:103-119.

1970. Parastygarctus sterreri n. sp., Tardigrade marin nouveau de l'Adriatique. Cah. Biol. Mar. 11:355-360.

1971. Tardigrades marins des Bermudes. Bull. Mus. Natl. Hist. Nat., Paris 42:1268-1276.

1974. Une nouvelle famille de Tardigrades marins abyssaux: les Coronarctidae fam. nov. (Heterotardigrada). C. R. Acad. Sci. Paris 278:3087-3090.

RENAUD-MORNANT, J., and M.-N. ANSELME-MOIZAN.

1969. Stades larvaires du Tardigrade marin Stygarctus bradypus Schulz et position systématique des Stygarctidae. Bull. Mus . Natl. Hist. Nat., Paris 41:883-893.

RENAUD-MORNANT, J., and L. W. POLLOCK.

1971. A review of the systematics and ecology of marine Tardigrada. Smithson. Contrib. Zool. 76:109-117.

RICHTERS, F.

1902. Beitrage zur Kenntnis der fauna der Umgebund von Frankfurt a. M. Ber. Seckenb. Naturforsch. Ges. 33(2):1-21.

1908. Marine Tardigraden. Zool. Anz. 33:77-85.

1909. Tradigraden-Studien. Ber. Senckenb. Naturforsch. Ges. $40(2): 28-44$.

RIEMANN, F.

1966. Die interstitielle Fauna im Elbe-Aestuar. Verbreitung und Systematik. Arch. Hydrobiol., Suppl. 31, 279 p. (see p. 223-225 and Fig. 57).
RIGGIN, G. T.

1962. Tardigrada of southwest Virginia: with the addition of a description of a new marine species from Florida. Tech. Bull. Va. Agric. Exp. Stn. 152:1-145.

ROBOTTI, C.

1971. Nuova specie di tardigrado marino: Styraconyx paulae (Heterotardigrada). Ann. Mus. Civ. Stor. Nat. "Giacomo Doria" 4(199):1-3.

RUDESCU, L.

1964. Tardigrada. Fauna Republicii Socialiste Populare Romania, Arthropoda 4(7):1-400.

SCHMIDT, $\mathrm{P}$

1968. Die quantitative Verteilung und Populationsdynamik des Mesopsammons am Gezeiten-Sandstrand der Nordseeinsel Sylt I. Faktorengeflige und biologische Gliederung des Lebensraumes. Int. Rev. Gesamten. Hydrobiol. 53:723-779.

1969. Die quantitative Verteilung und Populationsdynamik des Mesopsammons am Gezeiten-Sandstrand der Nordsee-Insel Sylt II. Quantitative Verteilung und Populationsdynamik einzelner Arten. Int. Revue Gesamten Hydrobiol. 54:95-174.

SCHULTZE, $M$.

1865. Echiniscus sigismundi, ein Arctiscoide der Nordsee. Ark, Mikrosc. Anat. 1:428-436.

SCHULZ, E.

1935. Actinarctus doryphorus nov. gen. nov. spec., ein merk würdiger Tardigrad aus der Nordsee. Zool. Anz. 111:285-288.

1951. Über Stygarctus bradypus n.g. n.sp., einen Tardigraden aus dem Küstengrundwasser, und seine phylogenetische Bedeutung. Kiel. Meeresforsch. 8:86-97.

1953a. Eine neue Tardigraden-Gattung von der pazifischen Küste. Zool. Anz. 151:306-310.

1953b. Orzeliscus septentrionalis nov. spec., ein neuer mariner Tardigrad an der deutschen Nordseekuiste. Kiel. Meeresforsch. 9:288-292.

1955. Studien an marinen Tardigraden. Kiel. Meeresforsch. 11:74-79.

STEINER, G.

1926. Bathyechiniscus tetronyx n.g. n.sp. Ein neuer mariner Tardigrade. Dtsch. Südpolar-Exped. 18:478-481.

THULIN, G.

1942. Ein neuer mariner Tardigrad. Medd. Goeteb. Mus. Zool. 99:1-10.

UHLIG, G.

1968. Quantitative methods in the study of interstitial fauna. Trans. Am. Microsc. Soc. 87:226-232.

VAN DER LAND, J

1968. Florarctus antillensis, a new tardigrade from the coral sand of Curaçao. Stud. Fauna Curaçao Caribb. Isl. 25:140-146. 
INDEX TO SCIENTIFIC NAMES

Actinarctus

doryphorus

15,21

Anisonyches

diakidius .

6,22

Archechiniscus

marci

2

$\ldots \ldots \ldots \ldots \ldots \ldots \ldots \ldots \ldots \ldots \ldots \ldots \ldots \ldots \ldots, 22$

Arthrotardigrada ........................ 21

Bathyechiniscus

tetronyx

13,21

Batillipedidae...................... 21

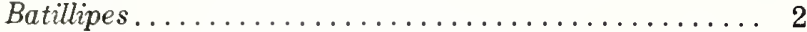

acaudatus .................. 7,21

annulatus ..................... 8,21

bullacaudatus ................ 8,21,22

carnonensis .................... 10,21

dicrocercus .................. 10,21, 22

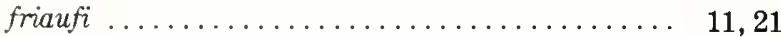

gilmartini ................... 9,21

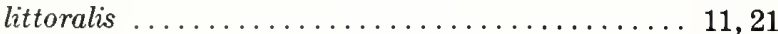

mirus ......................9, 9,21,22

pennaki.................. 9,21, 22

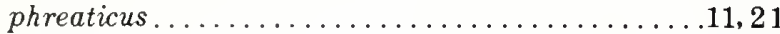

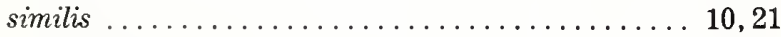

tubernatis ....................... 7,21

Coronarctidae ....................21

Coronarctus .......................... 2

tenellus ..................... 6, 21

Echiniscidae ....................... 22

Echiniscoidea ........................ 22

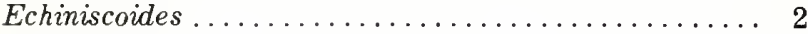

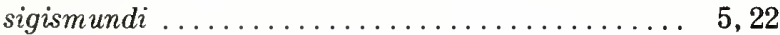

Echiniscus ...................... 6

quadrispinosus.................... 6, 22

Eutardigrada ..................... 2, 22

Florarctus

antillensis ................... 18, 21

heimi ................... 18,21

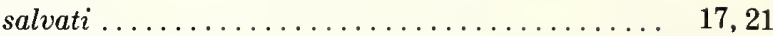

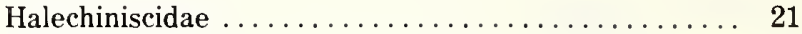

Halechiniscus ......................... 2

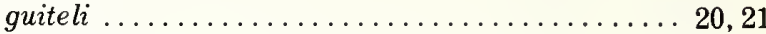

intermedius ..................... 19,21

perfectus..................... 20,21

remanei..................... 19,21

subterraneus .................... 20,21

Heterotardigrada .................... 21

Hypsibius

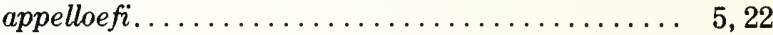

geddesi .................... 5, 22

stenostomus ..................... 4,22

Macrobiotidae ....................... 22

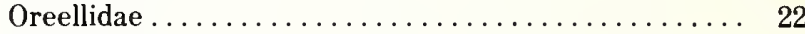

Orzeliscus

belopus . . . . . . . . . . . . . . . . . 12,21

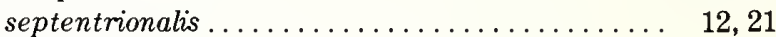

Parastygarctus ...................... 2

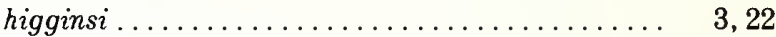

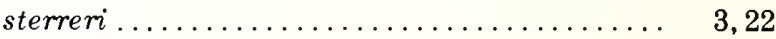

Pleocola

limnoriae ......................... 17, 21

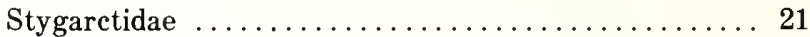

Stygarctus .......................... 2

bradypus....................4,21,22

granulatus ..................44,21,22

Styraconyx

haploceros ................... 14, 21

paulae .................... 14,21

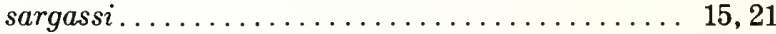

Tanarctus

arborspinosus ................... 16,21

tauricus ..................... 16,21

Tetrakentron

synaptae

$2,13,21$ 


\section{ACKNOWLEDGMENTS}

Preparation of the "Marine Flora and Fauna of the Northeastern United States" is being coordinated by the following Board:

Coordinator: Melbourne R. Carriker, Marine Studies Center, College of Marine Studies, University of Delaware, Lewes, DE 19958

Advisers: Marie B. Abbott, Marine Biological Laboratory, Woods Hole, Mass.

Arthur G. Humes, Boston University Marine Program, Marine Biological Laboratory, Woods Hole, Mass.

Wesley N. Tiffney, Department of Biology, Boston University, Boston, Mass.

Ruth D. Turner, Museum of Comparative Zoology, Harvard University, Cambridge, Mass.

Roland L. Wigley, National Marine Fisheries Service, Biological Laboratory, Woods Hole, Mass.
Robert T. Wilce, Department of Botany, University of Massachusetts, Amherst, Mass.

The Board established the format for the "Marine Flora and Fauna of the Northeastern United States," invites systematists to collaborate in the preparation of manuals, reviews manuscripts, and advises the Scientific Editor of the National Marine Fisheries Service.

I express my gratitude to Melbourne R. Carriker who, as director of the Systematics-Ecology Program, generously provided laboratory space at the Marine Biological Laboratory, Woods Hole, Mass. during portions of this work. My thanks as well to the stenographic service at Drew University for their assistance in the preparation of this manuscript. Many of the illustrations were drawn by Susan P. Heller, formerly with the Systematics-Ecology Program.

\section{COORDINATOR'S COMMENTS}

Publication of the "Marine Flora and Fauna of the Northeastern United States" is most timely in view of the growing universal emphasis on environmental work and the urgent need for more precise and complete identification of coastal organisms than has been available. It is mandatory, wherever possible, that organisms be identified accurately to species. Accurate scientific names unlock the great quantities of biological information stored in libraries, obviate duplication of research already done, and make possible prediction of attributes of organisms that have been inadequately studied.

Leland W. Pollock was awarded his Ph.D. from the University of
New Ilampshire in 1969 for work on the biology of intertidal Tardigrada. Both this doctoral research and the majority of subsequent postdoctoral research was conducted in association with the Systematics-Ecology Program at the Marine Biological Laboratory in Woods Hole. In 1972, he moved to his present position as a member of the zoology faculty at Drew University, Madison, N.J. where his studies on aspects of the systematies and ecology of marine Tardigrada continue.

Manuals are available for purchase from the Superintendent of Documents, U.S Government Printing Office, Washington, D.C. 20402. The manuals so far published in the series are listed below.

COOK, DAVID G., and RALPH O. BRINKHURST. Marine flora and fauna of the northeastern United States. Annelida: Oligochaeta. BORROR, ARTHUR C. Marine flora and fauna of the northeastern United States. Protozoa: Ciliophora.

MOUL, EDWIN T. Marine flora and fauna of the northeastern United States. Higher plants of the marine fringe.

McCLOSKEY, LAWRENCE R. Marine flora and fauna of the northeastern United States. Pycnogonida.

MANNING, RAYMOND B. Marine flora and fauna of the northeastern United States. Crustacea: Stomatopoda.

WILLIAMS, AUSTIN B. Marine flora and fauna of the northeastern United States. Crustacea: Decapoda.

POLLOCK, LELAND W. Marine flora and fauna of the northeastern United States. Tardigrada. 
370. Collecting and processing data on fish eggs and larvae in the California Current region By David Kramer, Mary J. Kalin, Elizabeth G. Stevens, James R. Thrailkill, and James R. Zweifel. November 1972, iv + 38 P. 38 figs., 2 tables. For sale by the Superintendent of Documents, U.S. Govern ment Printing Office, Washington, D.C. 20402.

371. Ocean fishery management: Discussions and research. By Adam A, Sokoloski (editor). (17 papers, 24 authors.) April 1973, vi +173 p., 38 figs. 32 tables, 7 appendix tables.

372. Fishery publications, calendar year 1971: Lists and indexes. By Thomas A. Manar. October 1972 , iv +24 p., 1 fig. For sale by the Superintendent of Documents, U.S, Government Printing Office, Washington, D.C. 20402

374. Marine flora and fauna of the northeastern United States. Annelida: Oligochaeta. By David G. Cook and Ralph O. Brinkhurst. May 1973, üi +23 p., 82 figs. For sale by the Superintendent of Documents, U.S. Government Printing Office, Washington, D.C. 20402.

375. New Polychaeta from Beaufort, with a key to all species recorded from North Carolina. By John H. Day. July 1973, xiü +140 p.. 18 figs., 1 table. For sale by the Superintendent of Documents. U.S. Government Printing Office, Washington. D.C. 20402 376. Bottom.water temperatures on the continental shelf, Nova Scotia to
New Jersey. By John B. Colton. Jr. and Ruth R. Stoddard. June 1973, iii t New Jersey. By John B. Colton. Jr. and Ruth R. Stoddard. June 1973, iii +
55 p. 15 figs., 12 appendix tables. For sale by the Superintendent of Documents, U.S. Government Printing Office. Washington, D.C. 20402.

377. Fishery publications, calendar year 1970: Lists and indexes. By Mary 377. Fishery publications, calendar year 1970: Lists and indexes. By Mary
Ellen Engett and Lee C. Thorson. December 1972, iv +34 p., 1 fig. For sale Ellen Engett and Lee C. Thorson. December 1972 , iv +34 p., 1 fig. For sale
by the Superintendent of Documents, U.S. Government Printing Office, Washington, D.C. 20402 .

378. Marine flora and fauna of the northeastern United States. Protozoa: Ciliophora. By Arthur C. Borror. September 1973, iii +62 p. 5 figs, For sale by the Superintendent of Documents, U.S. Government Printing Office, by the Superintendent

379. Fishery publications, calendar year 1969: Lists and indexes. By Lee C Thorson and Mary Ellen Engett. April 1973, iv +31 p., 1 fig. For sale by the Superintendent of Documents, U.S. Government Printing Office, Washington, D.C. 20402

380. Fishery publications, calendar year 1968: Lists and indexes. By Mary Ellen Engett and Lee C. Thorson. May 1973, iv + 24 p., 1 fig. For sale by the Superintendent of Documents. U.S. Government Printing Office, Washington, D.C. 20402
381. Fishery publications, calendar year 1967: Lists and indexes. By Lee C. Thorson and Mary Ellen Engett. July 1973, iv +22 p., 1 fig. For sale by the Superintendent of Documents, U.S. Government Printing Office, Washington, D.C. 20402 .

382. Fishery publications, calendar year 1966: Lists and indexes. By Mary Ellen Engett and Lee C. Thorson, July 1973, iv +19 p. 1 fig. For sale by the Superintendent of Documents, U.S. Government Printing Office, Washing ton, D.C. 20402.

383. Fishery publications, calendar year 1965: Lists and indexes. By Lee C. Thorson and Mary Ellen Engett. July 1973, iv +12 p., 1 fig. For sale by the Superintendent of Documents, U.S. Government Printing Office, Washington, D.C. 20402 .

384. Marine flora and fauna of the northeastern United States. Higher plants of the marine fringe. By Edwin T. Moul. September 1973, iü +60 p., 109 figs. For sale by the Superintendent of Documents, U.S. Government Printing office, Washington, D.C. 20402.

385. Fishery publications, calendar year 1972: Lists and indexes. By Lee C Thorson and Mary Ellen Engett. November 1973, iv +23 p., 1 fig. For sale by the Superintendent of Documents, U.S. Government Printing Office, Washington, D.C. 20402.

386. Marine Flora and fauna of the northeastern United States. Pycnogonida. By Lawrence R. McCloskey. September 1973, uii +12 p., 1 fig. For sale by the Superintendent of Documents, U.S. Government Printing Office. Washington. D.C. 20402

387. Marine flora and fauna of the northeastern United States. Crustacea: Stomatopoda. By Raymond B. Manning. February 1974, iii +6 p., 10 figs. For sale by the Superintendent of Documents, U.S. Government Printing Office, Washington, D.C. 20402

388. Proceedings of the first U.S.-Japan meeting on aquaculture at Tokyo Japan, October 18-19. 1971. William N. Shaw (editor). (18 papers, 14 authors.) February 1974. iii +133 p. For sale by the Superintendent of Documents, U.S. Government Printing Office, Washington, D.C. 20402.

389. Marine flora and fauna of the northeastern United States. Crustacea Decapoda. By Austin B. Williams. April 1974, iii +50 . 111 figs, For sale by the Superintendent of Documents, U.S. Government Printing Office, Washington, D.C. 20402.

390. Fishery publications, calendar year 1973: Lists and indexes. By Mary Ellen Engett and Lee C. Thorson. September 1974, iv +14 p. 1 fig. For sale by the Superintendent of Documents, U.S. Government Printing Office, Washington, D.C. 20402 
UNITED STATES

DEPARTMENT OF COMMERCE

PENN STATE UNIVERSITY LIBRARIES

ONAL OCEANIC AND ATMOSPHERIC ADMINISTRATION

NATIONAL MARINE FISHERIES SERVICE

ROOM 450

1107 N.E. ASTH ST.

SEATTLE. WA 9810 S

OFFICIAL BUSINESS

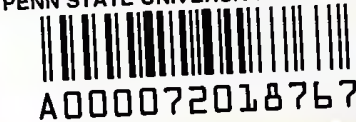

POSTAGE ANO FEES PAID U.S. DEPARTMENT OF COMMERCE $\operatorname{COM} 210$

THIRD CLASS

BULK RATE

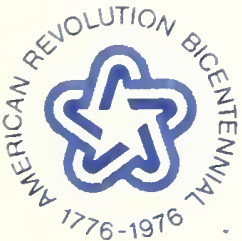

